
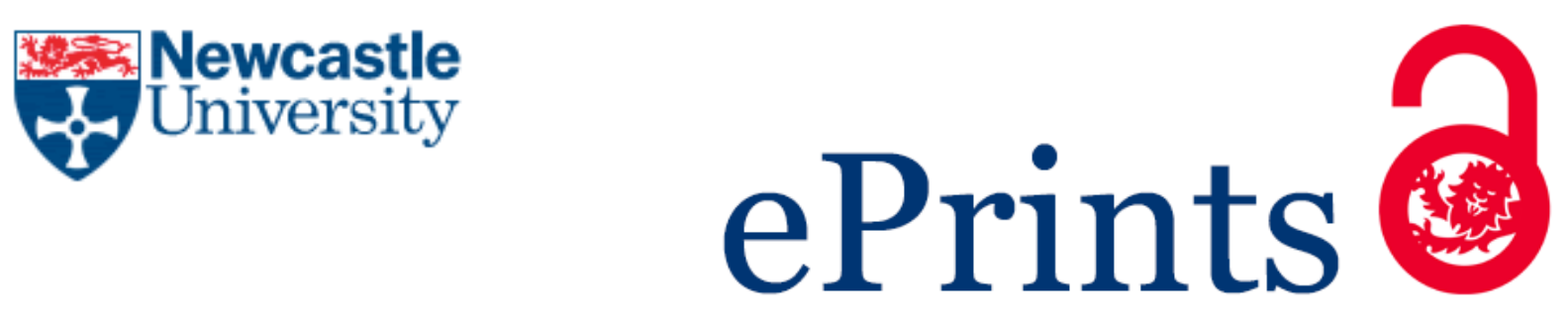

Westerink J, Jongeneel R, Polman N, Prager K, Franks J, Dupraz P, Mettepenningen E.

Collaborative governance arrangements to deliver spatially coordinated agrienvironmental management.

Land Use Policy 2017, 69, 176-192

\title{
Copyright:
}

(C) 2017. This manuscript version is made available under the CC-BY-NC-ND 4.0 license

DOI link to article:

https://doi.org/10.1016/j.landusepol.2017.09.002

Date deposited:

$20 / 09 / 2017$

Embargo release date:

20 September 2018

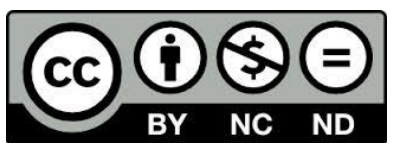

This work is licensed under a

Creative Commons Attribution-NonCommercial-NoDerivatives 4.0 International licence 
31 August final resubmitted version

\section{Collaborative Governance Arrangements to Deliver Spatially Coordinated Agri-Environmental Management}

Several studies show that agri-environment schemes (AES) are likely to be more effective if they are designed at the landscape scale. However, this requires spatial coordination of environmental management across multiple farm holdings and collaboration among governmental and other actors, including, possibly, groups of farmers. In this study we analyse alternative approaches to spatial coordination and collaboration. Through case studies from five EU member states in North West Europe we analysed collaborative governance arrangements, from the perspective of the distribution of governance tasks among collaborating actors and changes to these over time. Of these governance tasks, spatial coordination had our particular interest. The collaborative governance arrangements were shaped in various ways. In four out of five case studies a group offarmers had become involved in the performance of more governance tasks over time. In all cases a professional(ized) organisation (governmental organisation or a group of farmers) was responsible for spatial coordination, possibly due to the complexities inherent to a landscape approach. In relation to the change of schemes over time, we argue that adaptive collaborative governance, incorporating learning, monitoring and evaluation in the governance arrangements, is key to effective agri- environmental management.

(Keywords: Agri-Environment Schemes, landscape approach, farmer groups, cooperation, adaptive governance.) 


\section{Introduction}

Agri-environment schemes (AES, recently renamed AECS to include climate measures) became a mandatory element in all EU member states' Rural Development Plans in the Common Agriculture Policy (CAP) in 1994. AES are a key mechanism for supporting a wide range of environmental services from farmland (including biodiversity and landscape conservation). These schemes have evolved over the years as a result of changing public awareness and policy priorities, and the experience gained from their implementation. However, although AES payments involve $€ 2.5$ billion of EU funds per year, biodiversity in many rural areas is still declining rapidly (Berendse et al., 2004; Burns et al., 2016; EEA, 2015; Flohre et al., 2011). Although research has identified some positive environmental impacts arising from AES, many studies agree there is need for further improvements (Batáry et al., 2015; de Snoo et al., 2013; Jongeneel and Polman, 2014; Kleijn et al., 2004; Kleijn et al., 2011; Kleijn and Sutherland, 2003). A key insight is the need to adopt a landscape scale approach, one that matches agri-environmental management to the spatial scale of priority habitats, water systems and landscape features, such as stone walls and hedges (Dwyer, 2014; Franks, 2011; Kleijn et al., 2011; Merckx et al., 2009; Prager et al., 2012; Westerink et al., 2015).

However, a landscape scale approach requires governance arrangements that are able to deliver cross-holding spatial coordination of environmental management (Dutton et al., 2008; Schouten et al., 2013). This need has been acknowledged in the most recent reform of the CAP. AES compensation payments are now allowed to be paid to "groups of farmers, or groups of farmers and other land-managers" (Regulation (EU) No 1305/2013, article 28, subclause 2). Thus Article 28 opens up possibilities for the development of innovative collaborative governance arrangements for the delivery of agri-environmental services. 
Governance is defined as "the structures and processes by which people in societies make decisions and share power, creating the conditions for ordered rule and collective action, or institutions of social coordination" (Schultz et al., 2015, p. 7369). Collaborative governance can be understood as "the processes and structures of public policy decision making and management that engage people constructively across the boundaries of public agencies, levels of government, and/ or the public, private and civic spheres in order to carry out a public purpose that could not otherwise be accomplished" (Emerson et al., 2012, p. 2). Governance arrangements for the delivery of agri-environmental management may take various forms, as actor networks, agri-environmental policy and institutional frameworks are different between countries and regions (Bamière et al., 2013; Dupraz et al., 2009; Hodge, 2007; Westerink et al., 2015). This article analyses five case studies of collaborative governance arrangements drawn from different EU member states (France, Belgium, England, Germany and the Netherlands) to illustrate alternative approaches to delivering spatially coordinated agri-environmental management across farm holdings.

While CAP legislation is a major, it is not the only driving force behind the development of AES in the European Union. Governance, institutional arrangements for coordination and collaboration, and design of schemes are intricately related (Emery and Franks, 2012; Falconer, 2000; Franks, 2011; Mettepenningen et al., 2013; Westerink et al., 2015). One aim of this article is to contribute to a better understanding of these relationships. Differences in environmental priorities and governance cultures have influenced the way individual schemes have developed (their path dependency), and means that "cutting and pasting' entire AES from one member state or region to another is unlikely to be successful. However, this review of the development path of five examples of collaborative AES governance aims to generate transferable lessons, taken from real world examples and 
experiences, as innovations often spring from tailoring ideas found elsewhere to one's own circumstances and needs (Barzelay, 2007).

This comparative study is timely. Not only because of the need for AES to deliver environmental improvements, or because CAP-based AES can now offer higher and more directed payment incentives to farmers to manage their environment as members of farmer groups, but also because analyses of the actual organisation of spatially coordinated and/ or collaborative AES are not readily available (see OECD, 2013 for a recent overview).

Scientific articles analysing collaborative governance arrangements for AES are scarce: despite many articles advocating spatial coordination and collaboration among farmers, few analyse actual case studies (examples are Steingröver et al., 2010; Westerink et al., 2015; Westerink et al., 2017).

This article analyses the variety of collaborative governance arrangements used to deliver spatially coordinated agri-environmental management in different EU member states. The next section presents our conceptual framework; this is followed by the methods used. The case studies are described with reference to the annex with supplementary material. The discussion analyses the change in the distribution of the AES-related governance tasks between actors over the duration of the case study. It also analyses how the governance task of spatial coordination is implemented in the various settings and considers the extent to which current governance arrangements have been informed by previous experiences.

\section{Conceptual framework}

\section{Landscape approach and spatial coordination}

From the perspective of ecosystem functioning and services, there are good reasons to strive for spatial coordination of agri-environmental management across farm holdings within a 
landscape. Various ecosystem services targeted by agri-environmental policies, such as water quality and storage, wildlife conservation and the protection of cultural landscape structures, are more connected to the landscape level than to the single farm level (Gabriel et al., 2010; Herzon and Helenius, 2008; Merckx et al., 2009; Opdam et al., 2001). Single farms or plots are often simply too small to secure effective delivery of such services (McKenzie et al., 2013). For example, individual elements within landscapes, such as buffer sites, habitat stepping stones and ecological corridors are better able to contribute to strengthening the resilience of ecological networks when their location is related to existing environmental features (Franks and Emery, 2013; Geertsema et al., 2002; Opdam et al., 2006; Opdam et al., 2003; Schouten et al., 2013). Recent studies show that strengthening this type of intricate green-blue infrastructure improves landscape permeability, which favours species mobility: this thus facilitates a critical adaptation strategy to offset the impacts of climate change (Fahrig, 2003; Franks and Emery, 2013; Van Teeffelen et al., 2015).

However, the enhancement of ecosystem services at the landscape level requires the combined efforts of several land holders in ways which strengthen and complement each other. This requires careful planning of what to do and when and where to do it, and an understanding of the quality, intensity and density of on-farm measures required to achieve the desired level of ecosystem service delivery (Dutton et al., 2008). This spatial coordination can be achieved by a number of mechanisms (see for instance Boulton et al., 2013). It can be done by means of a landscape design by a governmental or an external agency, which allocates management options to specific sites, for which the individual farmers are personally invited to participate (Boulton et al., 2013; Dutton et al., 2008). Guidance, advice and facilitation can be provided by government agencies, independent consultants, professionals employed by a farmer group or conservation NGOs (Prager, 2015b). In addition, the actual design of AES can create landscape scale impacts by default, reducing or eliminating the need 
for either farmer-farmer collaboration or third party coordination. For example, increasing the inter-connectedness of habitats across the landscape can be steered by limiting the number of management options available for specific landscapes. Because a critical mass of participants is required to ensure sufficient coverage in targeted landscapes, schemes could be designed so that payments are only awarded above a pre-determined participation rate (Appleton, 2002). In addition, a scheme could include specific incentive mechanisms with or without agglomeration bonuses depending on the suitable spatial distribution of farmers' efforts (Bamière et al., 2013; Kuhfuss et al., 2016). An alternative to spatial coordination being imposed 'from above' or organised 'from outside' is for the spatial coordination to be organised by the farmers themselves (Mills et al., 2011; Westerink et al., 2015). With a view to enhancing landscape approaches and collaboration, the recent change in the CAP regulations now allows groups of farmers to be the end-beneficiaries of agri-environmental payments (see consideration 29 opening the Regulation (EU) 1305/2013).

\section{Collaborative governance}

The search to raise the effectiveness of ecosystem service delivery is an important explanation for the scholarly interest in collaboration. For the purpose of this article we distinguish collaborative management and collaborative governance. Collaborative management refers to the collaboration among land managers who are involved in actually carrying out management activities on-the-ground, while collaborative governance refers to the involvement of governmental and non-governmental actors in the processes and structures of decision making and management at the scheme level.

Previous studies have focussed on collaborative management among land managers in agri-environmental management (Boulton et al., 2013; Jongeneel and Polman, 2014; OECD, 
2013; Prager, 2015b). Collaboration offers farmers advantages over and above the increased effectiveness of their agri-environmental efforts. Rural communities often consider their landscape as part of their rural identity, and collaboration in local groups is a means to organise collective action to preserve this identity (see for example Mills et al., 2011; Primdahl and Kristensen, 2011). Working with one-other can build social capital and allow sharing of ideas, which in turn can generate new knowledge. We consider social capital as the soft qualities of networks and relationships that enable groups to achieve things together, including trust, access to knowledge and support, shared values and the capacity to learn and innovate as a group (Bodin and Crona, 2008; Mathijs, 2003; OECD, 2013; Pretty, 2003; Wolz et al., 2010). In addition, working in farmer groups may reduce each farmer's transaction costs. For instance, a farmer group may supply assistance to farmers in application procedures and farmer-to-farmer advice in the field, or a group can share advisory services and access help to develop and submit scheme applications (Falconer, 2000; Franks, 2010; Polman and Slangen, 2008; Polman et al., 2011). Additionally, by joining forces and through their contacts with advisors and government officials, farmer groups are better placed to influence policies (Polman, 2002) and to contribute to the design of AES and measures. For example, farmer groups have helped tailor schemes to better integrate local landscape issues into their farming systems (Beckmann et al., 2009; Prager and Freese, 2009; Prager and Nagel, 2008).

The latter studies of farmer involvement in agri-environmental policy making are examples of collaborative governance. Collaborative opportunities between farmers and citizens, wildlife organisations, research institutes and governmental agencies at various levels of government create larger networks (Prager, 2015b). In the collaborative governance arrangements of AES, these actors can be responsible for various tasks involved in the governance of the schemes, in varying network constellations (Westerink et al., 2017). We operationalise collaborative governance arrangements as the ways in which governance tasks 
related to the AES are distributed among collaborating actors. Figure 1 lists the twelve tasks we identified based on Eggers et al. (2007), Mettepenningen et al. (2011) and Weber (2015). It is such division of labour, which is related to the different qualities and resources that are available to the various collaborating partners, that makes collaboration attractive and can make it effective. Exactly how these tasks are divided in practice is an issue that has to be resolved by each collaborative network in turn (Schut et al., 2013).

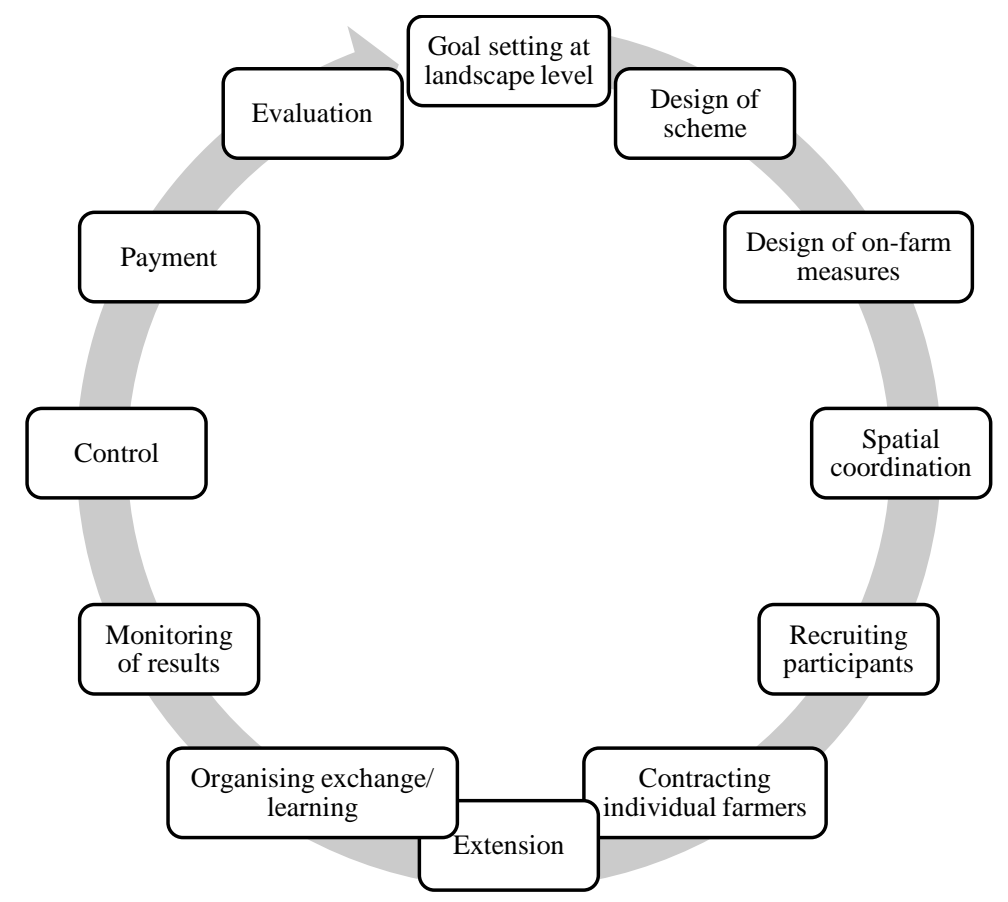

Figure 1: Twelve tasks involved in the governance of agri-environment schemes. Evaluation may lead to adaptation of the scheme, entering a new cycle.

\section{Adaptive governance}

Collaborative governance processes need cycles of adaptation to deal with changing environments and to incorporate learning (Emerson et al., 2012; Mc Dougall and Ram Banjade, 2015; Schusler et al., 2003). As landscapes can be considered as complex social- 
ecological systems that are prone to change and uncertainty, adaptive governance arrangements are required which are able to learn from the impacts of environmental management and adapt the strategies on the basis of lessons learnt (Armitage et al., 2009; Emerson et al., 2012; Folke et al., 2005; Westerink et al., 2017). Such an adaptive, learning approach is relevant in the light of evolution of AES, in which new schemes incorporate lessons from the experience with the previous ones. Unfortunately, often adaptation of schemes is pragmatic and political and innovation is constrained by administrative considerations (Chartier et al., 2016; Prager and Freese, 2009).

In line with the above, we distinguish adaptive governance at the level of AES and adaptive management at the level of farmer-to-farmer collaboration and implementation of agri-environmental management in the field. Adaptive management by farmers involves learning from the results of management actions to adapt their management activities accordingly (Olsson et al., 2004). Farmer-farmer collaboration in agri-environmental management facilitates social learning based on feedback from the results of management activities, and from farmer-farmer discussions in ways that are not possible for coordination of schemes by external parties. The development of AES shows that learning from results is essential: therefore more collaboration between farmers would be expected to deliver more effective AES (Burton and Schwarz, 2013).

\section{Method}

We used an explorative case study approach to reveal the variety of ways landscape scale environmental management can be implemented. A case study approach is ideally suited when complex issues need to be explored from a holistic perspective and in situations where 
the context in which decisions are made is important (Hussey and Hussey, 1997). The selection criteria used to identify the case studies were;

- examples of landscape approaches with spatial coordination,

- involvement of public funding,

- representing a diversity of landscapes and environmental issues,

- with detailed information available, particularly about how the schemes have changed over time,

- having at least two distinctive periods with respect to the degree and intensity of collaboration.

After scoping a larger number of potential cases involving spatial coordination of agrienvironmental management and collaboration, and taking into account time and budget constraints, we selected a subset of five cases. Four cases show an increase in involvement of farmer groups and the fifth case was selected as a deviant case to explore an opposite movement (see Seawright and Gerring, 2008). All five cases are located in the northwest of the EU, but in different EU member states, thus reflecting different institutional settings. In addition, the cases differ with respect to: year of change, number and type of participants, farming type and scheme objective. They also vary from regional applications of a national scheme to locally or regionally developed schemes, with and without co-financing from CAP. A brief overview of the case studies and some of their characteristics is provided in Table 1.

We based the analysis on existing material that each contributing author had collected from his or her own country's case study in previous research into collaborative approaches and landscape scale agri-environmental management. The available data (interview transcripts, official and group internal documents) were complemented with in total two phone interviews to fill specific knowledge gaps. In addition to the case descriptions in the 
following section, we present in tables (available in the annex) how the twelve governance tasks introduced in Figure 1are distributed between governmental actors, farmer groups, and third parties. For each case study we counted the number of tasks performed for each category of actor in two phases of the development of the case to demonstrate the work load connected to collaboration. Tasks involving two types of actor were counted twice, tasks involving all three categories of actors were counted three times. In addition to this quantitative analysis, we undertook a qualitative comparative analysis of the ways in which spatial coordination is organised and of how the tasks are distributed among actors. The detailed results for each case are displayed in Annex 1-5, with summaries presented in the results (Table 1) and discussion section (Table 2).

\section{Results from case studies}

This section describes each of the five case studies: Arguenon Water Basin (AWB) in France; Agrobeheercentrum (Eco2) in Flanders, Belgium; the Higher Level Stewardship, environmental management option HR8 in England, United Kingdom; Stiftung Rheinische Kulturlandschaft (SRK) in Germany; and Water, Land and Dijken (WLD) in the Netherlands (see annex for more detailed information on each of these cases). 
Table 1 Case studies and their selected descriptive characteristics

\begin{tabular}{|c|c|c|c|c|c|}
\hline Case study & $\begin{array}{l}\text { Arguenon Water } \\
\text { Basin (AWB) }\end{array}$ & $\begin{array}{l}\text { Agrobeheercentrum } \\
\left(\text { Eco }^{2}\right) \text { with } \\
\text { Agrobeheergroepen } \\
\text { (ABGs) e.g. in the } \\
\text { Dommel Valley }\end{array}$ & $\begin{array}{l}\text { Environmental } \\
\text { Stewardship Scheme } \\
\text { (ESS): Higher Level } \\
\text { Stewardship, option } \\
\text { HR8 }\end{array}$ & $\begin{array}{l}\text { Stiftung Rheinische } \\
\text { Kulturlandschaft (SRK) }\end{array}$ & $\begin{array}{l}\text { Water, Land and } \\
\text { Dijken (WLD) }\end{array}$ \\
\hline Country & France & Belgium & England & Germany & Netherlands \\
\hline $\begin{array}{l}\text { Starting } \\
\text { year }\end{array}$ & 1997 & 2008 & 1994 (precursor WES) & 2003 & 1996 \\
\hline $\begin{array}{l}\text { Year of } \\
\text { major } \\
\text { change }\end{array}$ & 2008 & 2008 & 2005 (until 2015) & 2003 & 2016 \\
\hline Region & $\begin{array}{l}\text { Bretagne NUTS2 } \\
\text { Region, Côtes- } \\
\text { d'Armor NUTS3 } \\
\text { Region, Arguenon } \\
\text { Water basin }\end{array}$ & $\begin{array}{l}\text { Valley of the river } \\
\text { Dommel, consisting of } \\
4 \text { municipalities: Peer, } \\
\text { Neerpelt, Bochelt, } \\
\text { Hamont-Achel }\end{array}$ & $\begin{array}{l}\text { HR8 can only be used } \\
\text { in ESS, HLS } \\
\text { agreements. HLS } \\
\text { agreements can apply to } \\
\text { any area of England, } \\
\text { but relatively few occur } \\
\text { outside specific high } \\
\text { nature value target } \\
\text { areas. }\end{array}$ & $\begin{array}{l}\text { Rheinland (part of the } \\
\text { Bundesland Nordrhein- } \\
\text { Westfalen) }\end{array}$ & $\begin{array}{l}\text { Part of province of } \\
\text { Noord-Holland, } \\
\text { located north of } \\
\text { Amsterdam between } \\
\text { the coast of the North } \\
\text { Sea and the dykes of } \\
\text { the IJsselmeer }\end{array}$ \\
\hline Area & $\begin{array}{l}\text { Immediate } \\
\text { protection perimeter } \\
\text { is } 226 \text { ha, the } \\
\text { protection of close } \\
\text { perimeter is } 2.300 \\
\text { ha, } 506 \text { ha engaged } \\
\text { in agri- } \\
\text { environmental } \\
\text { management (2015) }\end{array}$ & $\begin{array}{l}\text { In total, about } 110 \text { ha } \\
\text { was managed in } 2015\end{array}$ & $\begin{array}{l}\text { In } 2014,102,000 \text { ha of } \\
\text { land were covered by } \\
\text { option HR8. }\end{array}$ & $\begin{array}{l}\text { In total, about } 520 \text { ha } \\
\text { were managed in the } \\
\text { year } 2016 \text { in the area of } \\
\text { districts Köln and } \\
\text { Düsseldorf }\end{array}$ & $\begin{array}{l}\text { Working area is about } \\
50,000 \text { ha, } \\
\text { predominantly } \\
\text { farmland (pasture), of } \\
\text { which app. 5,480 ha is } \\
\text { under AES (2016). }\end{array}$ \\
\hline
\end{tabular}




\begin{tabular}{|c|c|c|c|c|c|}
\hline Case study & $\begin{array}{l}\text { Arguenon Water } \\
\text { Basin (AWB) }\end{array}$ & $\begin{array}{l}\text { Agrobeheercentrum } \\
\left(\mathrm{Eco}^{2}\right) \text { with } \\
\text { Agrobeheergroepen } \\
\text { (ABGs) e.g. in the } \\
\text { Dommel Valley }\end{array}$ & $\begin{array}{l}\text { Environmental } \\
\text { Stewardship Scheme } \\
\text { (ESS): Higher Level } \\
\text { Stewardship, option } \\
\text { HR8 }\end{array}$ & $\begin{array}{l}\text { Stiftung Rheinische } \\
\text { Kulturlandschaft (SRK) }\end{array}$ & $\begin{array}{l}\text { Water, Land and } \\
\text { Dijken (WLD) }\end{array}$ \\
\hline $\begin{array}{l}\text { Participation } \\
\text { of farmers } \\
\text { and non- } \\
\text { farmers }\end{array}$ & $\begin{array}{l}810 \text { farms in the } \\
\text { water basin; } 45.000 \\
\text { ha of agricultural } \\
\text { land; (2015); } \\
\text { population served: } \\
170.000 \text { inhabitants }\end{array}$ & $\begin{array}{l}\text { The Dommel Valley } \\
\text { consist of four ABGs } \\
\text { (groups of farmers } \\
\text { doing agri- } \\
\text { environmental } \\
\text { management): ABG } \\
\text { Peer (Siberië): } 8 \\
\text { farmers; ABG Bocholt: } \\
11 \text { farmers; ABG } \\
\text { Hamont-Achel: } 6 \\
\text { farmers; ABG Neerpelt: } \\
4 \text { farmers }\end{array}$ & $\begin{array}{l}\text { In } 2014 \text { there were } 701 \\
\text { agreements }\end{array}$ & $\begin{array}{l}\text { Rheinischer } \\
\text { Landwirtschaftsverband } \\
\text { in cooperation with } \\
\text { Landwirtschaftskammer } \\
\text { Nordrhein-Westfalen. It } \\
\text { is a private trust/ } \\
\text { charity. Farmers are } \\
\text { contacted once funding } \\
\text { for a project is granted }\end{array}$ & $\begin{array}{l}500 \text { dairy farmers, } 100 \\
\text { civic members and } \\
600 \text { volunteers } \\
\text { helping in on-farm } \\
\text { nature management }\end{array}$ \\
\hline $\begin{array}{l}\text { Main } \\
\text { objective of } \\
\text { initiative / } \\
\text { scheme }\end{array}$ & $\begin{array}{l}\text { Improve water } \\
\text { quality: (1) lower the } \\
\text { nitrate content } \\
<50 \mathrm{mg} / 1 ;(2) \\
\text { cleaning of } 10 \text { to } 11 \\
\text { million m3 water / } \\
\text { year }\end{array}$ & $\begin{array}{l}\text { Providing landscape } \\
\text { maintenance services } \\
\text { and management of } \\
\text { interconnected buffer } \\
\text { strips alongside brooks } \\
\text { and rivers by farmer } \\
\text { groups }\end{array}$ & $\begin{array}{l}\text { HR8 was targeted at } \\
\text { "common land and } \\
\text { areas of shared grazing } \\
\text { that have two or more } \\
\text { active graziers" }\end{array}$ & $\begin{array}{l}\text { Promoting nature } \\
\text { conservation and } \\
\text { cultural landscape. }\end{array}$ & $\begin{array}{l}\text { AES provision, } \\
\text { meadow birds } \\
\text { protection (including } \\
\text { Blacktailed godwit, } \\
\text { Lapwing, Common } \\
\text { redshank and } \\
\text { Shoveler) }\end{array}$ \\
\hline $\begin{array}{l}\text { Farming } \\
\text { systems }\end{array}$ & $\begin{array}{l}\text { Intensive farming } \\
\text { (Polyculture, pig, } \\
\text { cattle, poultry) }\end{array}$ & Diverse & $\begin{array}{l}\text { Beef and sheep farming } \\
\text { predominates in upland } \\
\text { commons agreements. }\end{array}$ & $\begin{array}{l}\text { Mainly intensive arable } \\
\text { farming (e.g. cereals, } \\
\text { oil seed rape) }\end{array}$ & $100 \%$ dairy farming \\
\hline
\end{tabular}




\section{Arguenon Water Basin (France)}

The deterioration of the water quality in the Arguenon Water Basin (AWB; Bretagne, NorthWest France) in the years leading up to 1997 resulted in the creation of the Arguenon Penthièvre Association, a municipality association which took specific responsibility for overseeing the quality of drinking water. Over the period described in this case study, governance changed from the voluntarily participation of farmers to the imposition of mandatory agri-environmental practices combined with reallocation of land between affected farmers through voluntary land purchase.

Between 1997 and 2002, a regional programme was negotiated (Bretagne Eau Pure 2) between the French government and the NUTS2 Regional council to govern water quality. This programme mainly relied on persuasion to mobilize farmer and non-farmer actors, for example to use pesticides more efficiently. However, in 2001 the European Court of Justice ruled that France was in breach of the Surface Water Directive on the protection of water used for the production of drinking water for a number of water catchments in Brittany, including Arguenon (Case C-266/99 from 8 March 2001). So in the years between 2003 and 2006 the main objective became to consolidate and spread water quality-friendly practices. However, many municipalities failed to operationalise these voluntary water catchment protection measures. The uptake of national and regional AES was very low, and participants were often located far from key areas within the catchments. In 2007, the European Commission confirmed that the case would be brought before the Court for a second time and asked the judge to impose a lump sum payment and a daily fine.

2007 was a transitional year in defining a comprehensive treatment of agricultural issues. Until then interventions had focused on the protection of the upper reaches of the water basin to Pleven, the drinking water catchment extraction point. After 2008, the Territorial Contract Watershed Arguenon "Source to Sea" programme was introduced to 
provide for the restoration of water quality and the aquatic environment throughout the entire drainage basin (2008-2010). The scheme imposed a legally binding reduction in nitrate use of 30\%. In the following 5 years (2008 to 2012) the compensation payments (Compensatory Allowance for Environmental Constraints, ICCE), which varied with farming systems, decreased each year. The scheme also identified a water quality protection perimeter, and divided land within this area into sensitive core areas and larger supplementary areas. Additional mandatory constraints were imposed on land use in core areas, for example, fields had to be forested or maintained in permanent grassland, and either mowed or grazed without disturbing the soil. In addition, agricultural land outside the protection perimeter was purchased by the Regional Council and sold to farmers who farmed within the perimeter but whose economic viability was jeopardized by these compulsory restrictions.

Under the Bretagne Eau Pure 2 Program (1997-2002), farmers formed groups which worked voluntarily with the public administration to decide on the design and implementation of AES. As the NUTS2 Regional branch of the Ministry of Agriculture supervised both the Bretagne Eau Pure 2 Program and the implementation of CAP AES, it was able to connect these two programs and integrated into their development the views of the farmer groups. However, this approach failed, partly because the scheme did not include the necessary farreaching modifications of farming practices and partly because of the voluntarily nature of the program: participation in key locations across the water basin was too low. In addition, the targeted area was too small to sufficiently impact the water quality in the basin. Nevertheless, the scheme raised awareness among farmers of the problem of water quality. This increased awareness helped to develop subsequent actions with municipality consortiums. After 2012, these consortiums are no longer the main policy makers. Instead, the newly designed actions are implemented through the state and regional governments under the leadership of national authorities, acting to improve the collective welfare by improving water quality to European 
health standards, thus avoiding sanctions from the EU Commission, and to coordinate the exchange of land between farmers. AES work in combination with these financial incentives to help implement these mandatory restrictions. In July 2015, the Arguenon water basin was officially removed from the list of French water basins that breach the Water Directive by the Environment Direction of the European Commission, after 3 years of good water quality.

The current French policy of 2014, implementing the CAP of 2013, introduces a new tool to enhance collective action of farmers and to promote "agroecological practices and systems". Since then, the number of such "Environmental and Economic Interest Groups" (GIEE) has grown fast from 135 groups in 2015 to 250 in mid 2016.

\section{Agrobeheercentrum Eco2 (Belgium)}

Although in Belgium group implementation of AES was not foreseen in legislation until the 2013 CAP reform (implemented in 2015), in the previous 15 years several farmer groups were already experimenting with collective agri-environmental management. For example, the poor maintenance of landscape elements encouraged a regional landscape organisation in WestFlanders to recruit a group of farmers, legally organized as a non-profit organisation, to address this problem. Those paying for these services, farmers and non-farmers in the region, also had to become members of the non-profit organisation (in order to be able to pay their contractors) as Belgian legislation did not allow farmers to offer landscape maintenance contracting for payments. In order to facilitate this, the farmer's organisation Boerenbond later on founded a special purpose cooperative company (with limited liability, Agro Aanneming). This legally allowed associated farmers to offer and be contracted for these types of activities. Over the years the West-Flemish cooperative has expanded its activities and now offers, for example, on-farm composting, chopping wood, and fence building. Whilst 
this group represents collaboration without explicit spatial coordination, other similar farmer groups did include spatial coordination. For example, in the Dommel valley the public organisation for water management "Watering" stimulated farmers to collaborate in the management of interconnected buffer strips alongside brooks and rivers in a landscape based approach.

In 2008, responding to the growing number of initiatives in rural Flanders, a number of organisations set up the project $\mathrm{ECO}^{2}$ (ECOlogy x ECOnomy), using finance provided from the European Regional Development Fund. A principal aim of the project was to initiate and guide agro-management groups (Agrobeheergroepen, $\mathrm{ABGs}$ ). The $\mathrm{ECO}^{2}$ project was a deliberate attempt to facilitate agri-environmental collaboration between farmers in order to stimulate a landscape approach, but also to explore how to make environmental management more economically attractive for farmers. The $\mathrm{ECO}^{2}$ project also established the non-profit organisation Agrobeheercentrum $\mathrm{Eco}^{2}$ (Agro management centre $\mathrm{Eco}^{2}$, from now on called $\mathrm{Eco}^{2}$ ) as an umbrella organisation of all ABGs, and as a knowledge centre for agrienvironmental management. Eco2 helps setting up ABGs and stimulates collaboration between farmers and other (local) actors. $\mathrm{Eco}^{2}$ prefers ABGs to be small, more or less informal groups (containing between 4 and 11 farmers, but larger is also possible), so that the farmers are better connected and a group feeling is created. The groups do not have any official legal form, but they adopt statutes and bylaws, and elect a management board every five years. Payments for the agri-environmental management activities are given through the earlier established vehicle of Agro Aanneming. $\mathrm{Eco}^{2}$ plays a role in redistributing the payment between farmers in the $\mathrm{ABG}$, in the case of farmers performing agri-environmental management on the land of other farmers in the ABG, and officially contracts with other parties in need of landscape management. The management is then outsourced to the farmers 
in the ABG through Agro Aanneming. For this coordinating role, $\mathrm{Eco}^{2}$ receives part of the payment.

Currently, there are 27 ABGs across Flanders that work towards objectives such as conservation of birds, erosion, water management, or landscape management. The farmers in the ABGs usually take up environmental management options from AES that were designed by the government, and there is no flexibility to adapt them to the local circumstances. Eco ${ }^{2}$, also working with its partner VLM (Flemish Land Agency, a government body), strives to spatially coordinate agri-environmental management, but in an informal way as this is not officially registered in management plans. Although the current Flemish rural development plan in principle allows agri-environmental payments to groups of farmers, at the time of writing of this article this was not yet administratively settled, and all contract payments are paid to individual farmers. So farmer members of an ABG who do not wish to carry out the environmental management themselves, enter into contracts which transfer this work and part of their payment (the management-related part, retaining the compensation for loss of income) to the contracted farmers. $\mathrm{Eco}^{2}$ acts as an intermediate, receiving and redistributing these compensation payments.

\section{HR8 “Supplement for Group Applications" (UK)}

The English case study describes the agri-environment overlaying option, HR8 "Supplement for Group Applications" as it is used on upland open commons in Higher Level Environment Stewardship Scheme (ESS) agreements (2005-2015). 57\% of upland common land is designated as high-environmental value Sites of Special Scientific Interest (SSSI) (NAO, 2008), and as the UK government has a Public Service Agreement to improve the environmental status of these areas, Natural England (NE), the government's Environmental 
Agency, has prioritised enrolling common land into agri-environment agreements. However, for this to happen, NE requires that all stakeholders on the common land agree to participate in an AES (Short, 2000). This is a particular problem for common land and where of the existence of rights beyond those associated with the conventional free-holder system, and where registers of all, or of even only the active rights-holders, are often incomplete or inaccurate (Short and Winter, 1999).

This difficulty in recruiting groups of farmers was addressed by the forerunner of HR8, the Wildlife Enhancement Scheme (WES). WES (1994 to 2008) was designed as a flexible, tailor made, site-specific scheme. It could be used in stand-alone agreements, or to "top-up" payments to either Environmental Sensitive Area (ESA) or Countryside Stewardship Scheme (CSS) agreements. NE required CSS/ESA+WES agreements covering common land to be negotiated by a single representative, nominated by all who held a legal interest in the land (for example, active and non-active graziers, non-farmer rights-holders, and owners of the commons). Therefore, NE paid an individual farmer, but that payment was shared by the group (Short, 2000).

In 2005 the Environmental Stewardship Scheme's (ESS) Higher Level Stewardship (HLS) was introduced, and this allowed farmers to select the HR8 option "Supplement for Group Applications". HR8 was an overlaying option which had to be combined with other environmental management options available under HLS (HLS+HR8). It was targeted to be used on "common land and areas of shared grazing" and could only be included in agreements that covered land "under more than one ownership that are to be managed for resource protection, inter-tidal flood management, and/or wetland management” (DEFRA, 2005, p. 108). It paid $£ 10 /$ ha of land included by the HR8 option, as compensation for the farmer group's transaction costs, for example, costs incurred arranging farmer-farmer meetings, and organising, submitting and managing their joint application. 
To include HR8 in a farm's HLS agreement, farmers with eligible farm-spanning environment features needed to agree to jointly manage the feature(s) and had to jointly select appropriate environmental management options that would apply across the feature(s). In addition to including option HR8, agreements over commons grazed by more than one farmer needed all stakeholders to agree with the selection of additional environmental management options. Natural England required each farmer group to open a bank account into which the entire HLS+HR8 payment would be paid, and to submit an internal agreement, signed by all relevant stakeholders. The terms of the internal agreement were allowed to vary to accommodate the wide range of farming arrangements found on open commons, but each agreement had to include full detail of the location of the management options, each parties' contributions to the scheme, and details on how the payment would be shared out between the group members. This allows for variation between internal agreements as to who is involved, who should receive a share of the payment, and the payments they are due (Short and Waldon, 2013, p. 8). A side-benefit of offering option HR8 is the revitalisation, and in some cases re-creation, of Commoners Associations - informal groups of farmers who farm the same area of common land (Short, 2000). The Commoner Associations often drew on the help of third parties, such as National Park Authorities and/or conservation NGOs, in their initial stages.

Importantly, the way the HLS is designed allows it to make an additional contribution to landscape scale environmental management. HLS agreements with individual farmers are predominately available in geographically small, high nature value areas, each of which focuses on its particular priority habitats and species. As a result farmers within the same HLS area must select from the same, very limited list of environmental management options. Additionally, all HLS agreements have to be signed off by an NE project officer. This project officer knows the environmental features across the entire landscape and can request changes 
to the submitted plan so they better take into account landscape features on neighbouring farms. These design features allow HLS to deliver a degree of landscape scale management in the absence of farmer-farmer collaboration or third party coordination, provided sufficient farmers within the same HLS area enrol in the scheme.

\section{Stiftung Rheinische Kulturlandschaft (Germany)}

In Germany, land use planning, nature conservation and landscape management are devolved to the federal states (Bundesländer). This has resulted in different policies and practices being adopted throughout the country. The dominant strategy for agri-environmental services consists of individual AES contracts with farmers, complemented with individual conservation agreements (VNS, not EU co-financed) in those states that have reserved budget for them. Landcare associations (LCAs, see Prager, 2015a) play an important role in many Länder, for instance in the implementation of Natura 2000 management, the monitoring and reporting of results, as well as the management of publicly owned marginal land that has no economic value to farmers. LCAs contract groups of farmers to manage this land according to conservation goals as part of projects. Membership is voluntary and groups may represent an extended network, which can include individuals representing farming, conservation, community, education, tourism, hunting, fishing or other interests (Prager, 2015a). In addition, local initiatives that are organized as trusts play an increasing role in e.g. Niedersachsen, Rheinland-Pfalz, Bayern, Sachsen-Anhalt and Nordrhein-Westfalen. They follow a cooperative approach in their work with land managers and also contract farmers.

The Stiftung Rheinische Kulturlandschaft (SRK) organisation is described in more detail. SRK is a private trust which has operated in the region of Köln and Düsseldorf (state of Nordrhein-Westfalen) since 2003. It differs from an LCA in that it can also buy land as a legal 
entity. The region is characterised by fertile soils and intensive arable farming, growing commodity crops such as cereals and oil seed rape. We consider the private trust to be mainly a 'farmer group' because it was jointly founded by the regional farmers' association and the Agricultural Chamber of the state. The farmers were concerned about the loss of agricultural land to urban development, and the related nature compensation measures. The establishment of SRK was triggered by a large federal conservation project aimed at identifying collaborative solutions to land use conflicts. As a trust, SRK does not have members, and its day-to-day work is carried out by a professional staff. However, its executive committee consists of representatives of the farmers' union, the Agricultural Chamber of the state and nature conservation organisations.

The aim of the SRK is "the promotion of nature and landscape protection, through maintaining and managing the uniqueness, biodiversity and beauty of the Rhineland farming landscape." The trust promotes conservation measures (species and habitat protection) and facilitates compensation measures on farmland. It performs spatial co-ordination by identifying suitable sites and environmental measures, and aims to secure these management activities permanently. It also works through keeping conservation areas in trust. The approach is characterised by voluntary participation of farmers, appropriate payments for clearly defined services, as well as consideration of the farming enterprise and agricultural structure. The trust works towards integrating economic and environmental interests of agricultural land management, and ensures that the practice of farming is considered when nature protection measures are designed and implemented. SRK coordinates individual farmers' efforts; typically there is no farmer-farmer collaboration. In individual projects, third parties may be involved.

SRK does not make use of the state's AES, but is funded on project basis by the federal level and by companies with interests in nature conservation. Additional money is 
donated by other trusts. SRK carries out pilot projects 'to demonstrate collaborative solutions', e.g. with a focus on protecting sparrows, pollinators, swallows, and plant species in arable fields, and producing seed mixtures of wild plants. SRK submits funding applications, and after a project is awarded identifies farmers who are willing to participate (where required). Ultimately, therefore, the effectiveness of their spatial coordination activities builds on the voluntary participation of individual farmers which is ex ante uncertain. These projects tend to be input or effort based. For larger projects, monitoring of results is planned and budgeted for as part of the application.

\section{Water, Land en Dijken (Netherlands)}

Individual and collaborative agri-environmental management has a long history in Dutch peat grassland areas. In the late nineteen seventies, a group of young farmers in one such area had already started to develop integrated agriculture and wildlife management at the landscape scale. Over the last 30 years, farmer groups have become institutionalised within Dutch agrienvironmental governance, and are now an integral part of the Dutch Rural Development Plan. For example, the environmental association Water, Land \& Dijken (WLD) is today an important actor in landscape management north of Amsterdam, applying local skills and involving relevant networks. In 2016, a tailor-made landscape management arrangement between WLD and the province of North-Holland started as part of the new Dutch AES (RDP 2016-2021).

In 1996, the environmental cooperative "Waterland" was officially founded (see the Water, Land \& Dijken case study in OECD, 2013). It delivered administrative services to an increasing number of farmers to support agri-environmental contracting. The size of the organisation increased with regard to membership and working area due to mergers with 
neighbouring environmental cooperatives, after which it changed its name to WLD, and became a more formalised organisation. But as a result of the expansion, the social distance between the association and individual farmers has increased.

From 2012 to 2014 the Dutch government experimented with new types of collaborative agri-environmental management, choosing WLD as one of its four pilot study areas. An important aim of the pilot studies was the development and trial of new collective schemes, in preparation for rolling them out across the country (Terwan and Rozendaal, 2014). The pilot allowed WLD to experiment with taking responsibility for additional governance tasks, one of which was spatial coordination. The WLD pilot found that the administrative procedures required to deal with the variety of situations encountered, and the need to develop tailor-made regional plans, proved to be time consuming (involving "a lot of paperwork"). However, farmers accepted WLD role being responsible for control and sanctioning. The determining factors for farmers accepting WLD to perform this role were transparency, comprehensive communication (through for example, newsletters and frequent meetings), social cohesion, protocols for monitoring, use of graduated sanctions, as well as trust farmers have in WLD's field coordinators. The farmers appreciate WLD's approach to requiring improvements from participants (as in contrast to control by governmental agencies): their first step was to explain to the farmer what he had done wrong, the second step was to explain that other consequences may follow, depending on the seriousness and context of the offence. Although the pilot was jointly evaluated from the angle of governance, WLD regretted afterwards that no ecological evaluation was done.

The current Dutch Rural Development Plan recognised WLD as a formal farmer group. Therefore, from 2016 onward, WLD is responsible for compiling a collective management plan for their area to apply for subsidy from the AES, recruiting and contracting farmers, and the control of delivery of agreed management options. WLD is also responsible 
for paying individual farmers in designated core areas and for the spatial coordination of farmers' individual agri-environmental management. Central to the new approach is that farmer group applications will only be granted in areas where cross-holding management is expected to enhance biodiversity. The suitability of such areas is assessed with respect to their physical landscape conditions and the existing populations of species. As a consequence, farmers can only receive agri-environmental payments if they are a member of a formal farmer group, and participation in AES is restricted to farmers who farm in pre-designated areas.

Another objective of this collective farmer approach is to reduce public as well as individual farmer's administrative costs associated with the AES by handing over some administrative responsibilities to the farmer groups. Typical measures in peat areas such as WLD's focus on preserving meadow bird species, including Blacktailed godwit, Lapwing, Common redshank and Shoveler. Good ecological conditions for these birds are wet grasslands, a diverse food source (related to grassland biodiversity), and a postponed mowing date. The new scheme allows the farmer group some flexibility in matching sites and measures to actual locations of nesting birds during the season.

\section{Discussion}

The governance arrangements outlined in the case studies vary widely with regard to the actors involved, their role in the process of scheme design and implementation, and the governance tasks they carry out. Despite this, each case study represents an example of collaborative governance which includes an element of spatial coordination of management activities, thus representing a landscape scale approach to AES. In particular, the case studies show how the task of spatial coordination is addressed in different contexts and at different 
geographical levels, ranging from national schemes to local initiatives. By comparing the two successive phases of each scheme (see the annex), we also illustrate the dynamic nature of governance arrangements. In the following, we discuss our findings according to the conceptual framework: spatial coordination, collaborative governance arrangements, and adaptation.

\section{Spatial coordination}

Each case study represents a landscape scale approach to AES. This allows the implementation of measures across farm holdings and thus a better management of watersheds (AWB), meadow birds (WLD), upland commons (HR8), landscape elements $\left(\mathrm{Eco}^{2}\right)$ and agricultural landscape biodiversity (SRK). The spatial coordination is achieved in the multiple ways: 1) designation of areas within which farmers can apply; 2) identification of suitable sites and measures and inviting farmers at those locations to participate; 3 ) development of joint management plans with or by groups of farmers; 4) limiting the number of available management options to such an extent, that neighbouring farmers are likely to select similar measures; 5) adjustment of spatial planning of measures to the seasonal behaviour of the target species; and 6) imposing compulsory environmental management on farmers in specific locations (Table 2). 
Table 2: Mechanisms for spatial coordination of environmental management across farm holdings in case studies and other organisational features

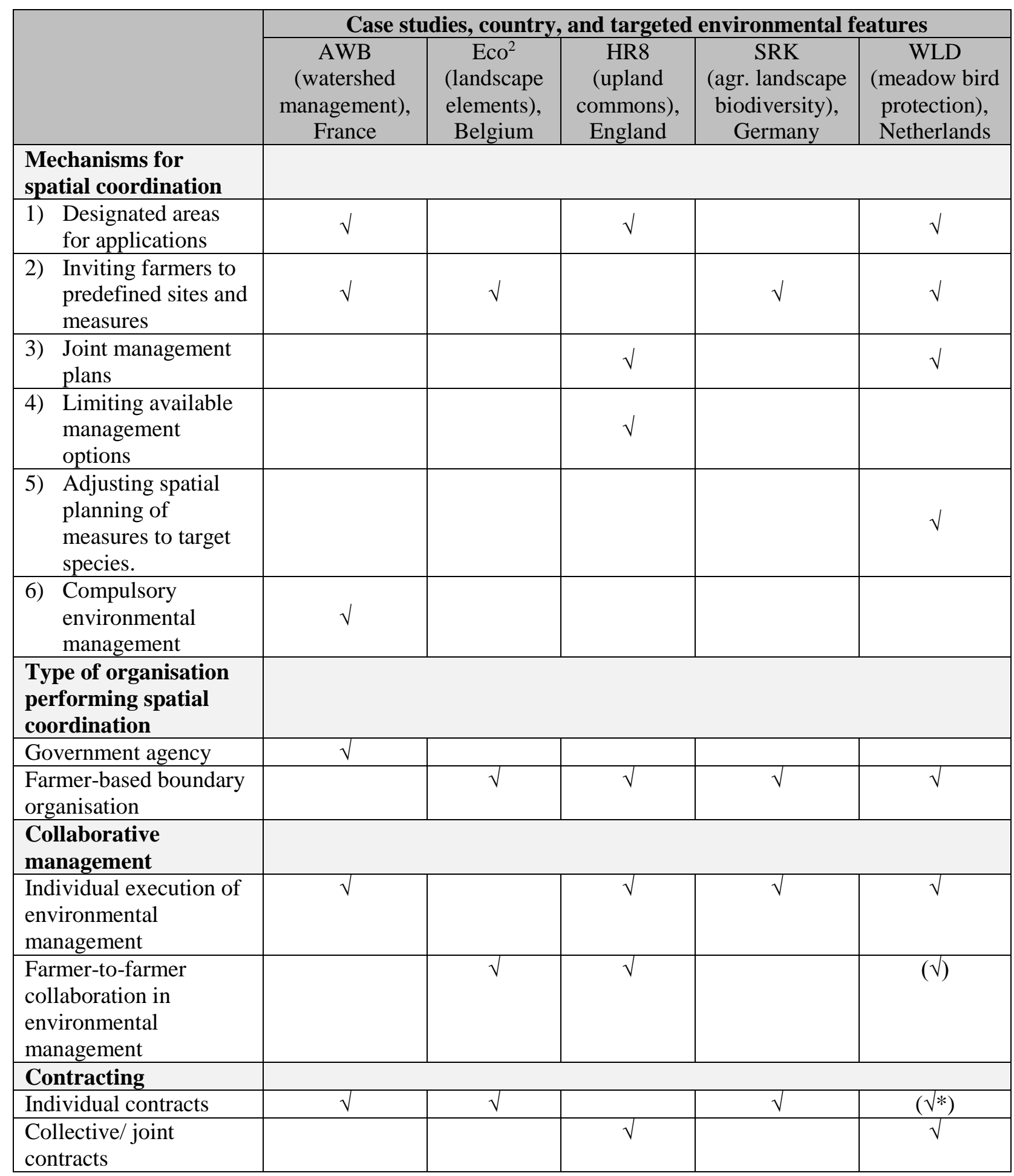

* Individual farmer has a contract with the farmer group, the farmer group has a contract with the government 
The case studies show that spatial coordination is often undertaken by professional organisations. This can be initiated by a governmental agency, such as Natural England, by a farmer group, or by a multi-stakeholder organisation. Our case studies suggest that spatial coordination of agri-environmental measures is such a complex task that it requires to be handled by professionals employed by a dedicated organisation. What we initially framed as 'farmer group' sometimes takes the shape of a professional farmers' organisation, or more precise, a farmer-based boundary organisation (Carr and Wilkinson, 2005; Franks, 2010). Eco2, SRK and WLD are (co-)founded by farmers or farmers' organisations and all operate on the boundary between the worlds of farmers and of other actors, including governments. Performing a number of governance tasks and mediating between farmers and governmental and non-governmental actors they have hybrid identities, SRK even being a multi-stakeholder organisation. Nevertheless, these farmer-based boundary organisations do not necessarily stimulate farmer-to-farmer collaborative management in the field: they may simply coordinate individual actions (Table 2).

This raises a question around the relationship between professionalism, size, and social capital within groups of farmers (OECD, 2013). A farmer group needs to have grown sufficiently large to allow it to develop the organisational capacity and institutional capital needed to professionalise. From studies the historical development of agricultural cooperatives we know that the need for professional management introduces a new class of officials whose interests, focus and concerns may run the risk to become different from those of the original participants (Bijman et al., 2014; Kaswan, 2014). This may create a disconnectedness that negatively impacts on member's involvement and commitment. These larger groups, therefore, need to find ways to combine the professionalism needed for spatial coordination with the social capital (connectedness, ownership) needed to maintain an active membership group. The case studies represent a number of solutions to this problem. 
Although upland HR8 agreements are often initiated by a government agency and $\mathrm{Eco}^{2}$ is an initiative of a farmers' organisation, they both build on farmer-to-farmer collaboration in small groups to develop and maintain social capital. $\mathrm{Eco}^{2}$ represents a nested structure of smaller groups, and while WLD is a merger of a number of agri-environmental co-operatives, other Dutch farmer groups have maintained their nested structure. Ostrom (1990) believes these nested structures are important for well-functioning self-governance when groups grow large, because smaller groups are more conducive to the development of social capital.

\section{Collaborative governance arrangements}

We now turn to the other tasks in the governance of the schemes and how the way they are distributed among the collaborating actors has changed over time. Figure 2 summarises these changes (for details on individual case studies and how they changed see Annex A1-A5). It provides an overview over time in each case study with respect to the development of the involvement of governmental actors, farmer groups and third parties in managing the various governance tasks associated with AES. All of the voluntary schemes show an increase in involvement of farmer groups and third parties over time. The first voluntary and later mandatory Arguenon water basin case study (AWB) is the exception. In this case, government has reassumed some control over the scheme's governance and stakeholder involvement in governance tasks decreased. 


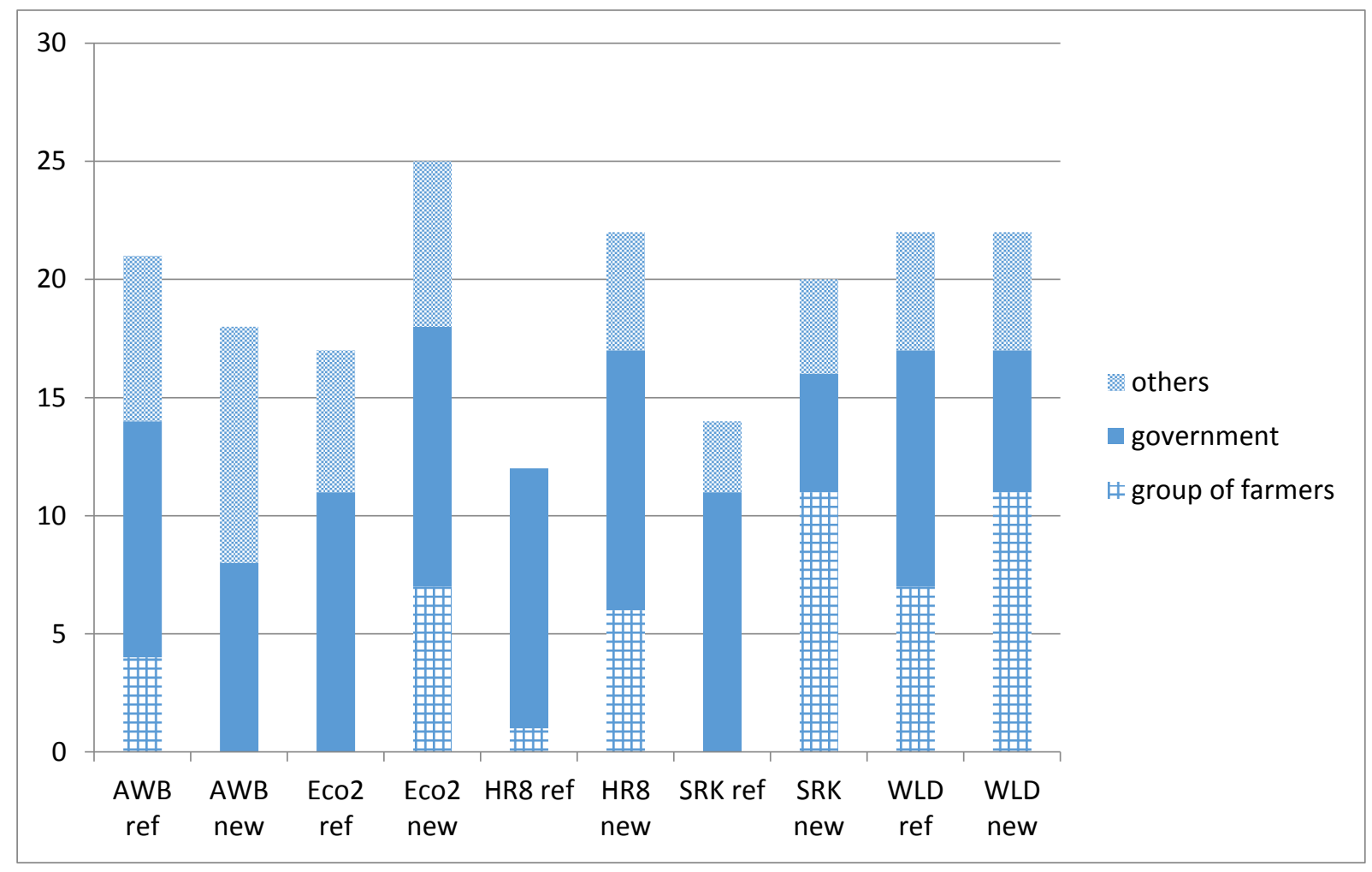

Figure 2: The number of governance tasks carried out by actors involved (government, farmer groups, third parties), and the change of the arrangement over time (reference and new situation compared)

The responsibility of government, in the sense of which governance tasks are performed, appears to be relatively stable over time for all cases except for WLD and SRK. In the reference situation of all the case studies, goal setting, spatial coordination, design of schemes, contracting, control, payment and evaluation were entirely managed by government. As the schemes have developed to the new situation, government generally maintains involvement in these activities, but now allows other parties to participate. In the case studies of SRK and WLD the number of tasks of government diminished. In the Netherlands, a decision was taken at the national level to give more responsibility to farmer groups, including being entirely responsible for recruiting participants, managing the spatial 
coordination of their activities, the control of these activities, arranging contracts and making the payments to individual farmers. SRK shows at a regional scale and on project basis how a farmer-based boundary organisation can perform recruiting of participants, contracting of individual farmers, control and payment without interference of government.

The number of tasks performed partly or wholly by farmer groups increased over time in all case study areas, except for the Arguenon water basin (AWB) case, where the role of the farmer groups in the governance of the AES was terminated. The Belgian $\mathrm{Eco}^{2}$ and the German SRK show a major change in the involvement of farmers, starting from a situation where they were not involved as a group. The number of tasks performed by farmer groups increased substantially within the English HR8 and the Dutch WLD case studies as well, but in those cases farmer groups had already been involved in a number of governance activities in the reference situation. The involvement of farmer groups in spatial coordination increased in three of the case studies, while their role in contracting participants was new in two cases. Involvement in making payment to farmers was introduced in the $\mathrm{Eco}^{2}$, WLD and SRK case studies. The role of farmer groups in recruiting and contracting of participants increased over time suggesting an increasing role of farmer self-organisation and internal collaboration in fulfilment of tasks.

As Figure 2 further shows, the role of third parties in the collaborative governance increased for most cases, in particular in the HR8 and WLD cases. For the AWB, involvement of third parties was and remained high compared to the other case studies. Also in in the reference situation for $\mathrm{Eco}^{2}$ and WLD involvement of third parties was already strong. Involvement of third parties in SRK remained limited. In the case of HR8, third parties were mainly involved in the preparation phases of the scheme.

The increased involvement of farmer groups and third parties in most of these case studies suggests that the governance associated with AES has become increasingly 
collaborative in nature. This collaboration is arranged in various ways, including a formal farmer group approach in the Netherlands. Our case studies show that a higher number of actors have become involved in governance tasks, which is likely to lead to higher levels of activities per task and therefore resulting in an overall increase in transaction costs. This is in line with literature, stating that more collaboration normally implies an increase in transaction costs (Beckmann et al., 2009; Hagemann et al., 2015). According to economic theory, any increase in transaction costs should ideally be compensated for by additional gains (Jongeneel et al., 2012; Mettepenningen et al., 2009; Shelanski and Klein, 1995). Actors apparently have good reasons for engaging in collaboration, in spite of the costs. Whether the Dutch approach results in the intended overall decrease in transaction costs remains to be seen.

The observed increase in collaboration in the case studies is accompanied by different institutional designs: SRK, $\mathrm{Eco}^{2}$ and AWB rely on individual contracts (the still dominating contract form in the EU for AES), whereas WLD follows the farmer collective approach with collective contracts. The new Dutch model excludes the possibility of individual contracts between government and farmers, implying that an institutional structure is imposed on them, which farmers and their organisations have to align with. The HR8 case represents a hybrid form which combines an internal agreement between farmers with a single agreement between the farmer group and the government agent (see Table 2).

\section{Adaptation and learning}

In addition to examining trends in collaboration and spatial coordination, the evolution of scheme design can be explored for evidence of learning and adaptation. The change of the scheme in the French case is an example of adaptation: a lack of effectiveness led to abandonment of the previous scheme. It changed from 'voluntary and collaborative' to 
'mandatory and individual' after the evaluation of results from water quality monitoring. However, learning about the complexity of the social-ecological system and especially the influence of the social part of the system on the ecological part did not take place, because social mechanisms that could have explained the failure of the first scheme were not considered, nor the positive outcomes of collaboration among farmers with respect to farmer awareness. In the Netherlands, effects of the previous scheme were monitored in terms of ecological indicators. In the new scheme, to improve effectiveness, this led to a reduction of areas eligible for agri-environment subsidies. The farmer group approach was a result of a pilot project involving four large, pre-existing (and professionally organised) agrienvironmental cooperatives. In sum, two learning strategies stood at the base of the new scheme, although not all innovations developed in the pilot were implemented (Terwan and Rozendaal, 2014). Also in England, lessons from the previous scheme were deliberately taken into account in the development of the new scheme; in particular by offering environmental management options which reflected local environmental priorities and existing cultural and agricultural practices. In Belgium-Flanders, the farmers' organisation and later Eco2 also learned from the experiences of the early initiatives. However, the German case illustrates the vulnerability of monitoring and evaluation. Here, monitoring is mainly carried out when funded as part of the individual project. A lack of funding for monitoring and data management can severely hinder learning from experiences and adaptive governance of schemes. Another concern is that organizing learning among participants, which would be a prerequisite for adaptive management, is only in a few cases part of the governance of the scheme (see Annex A1-A5).

\section{Conclusions}


This article compares the development of five Northwest European case studies of the spatial coordination of environmental management designed to deliver landscape scale impacts within AES. Although the analysis is based on only five case studies, this is sufficient to show the wide variation in approaches that can be used to deliver spatial coordination. The analysis shows how the change made to each scheme resulted in the reallocation of responsibilities for a range of governance tasks between collaborating actors, and we considered the extent to which this is a result of learning from previous experiences. We presumed that a landscape approach would require an increase in collaboration. In four of the five case studies, collaboration did increase, in the sense that more actors, and especially groups of farmers became involved in more governance tasks within the scheme. In the other case study, the involvement of a group of farmers was terminated with the change of the scheme. The increased involvement of farmer groups and other actors in the governance of two of the four schemes did not diminish the role of governmental actors: government remained involved in its traditional tasks. In the case of SRK in Germany, the farmer organisation performs quite a number of governance tasks without government involvement. In the national farmer group approach in the Netherlands, the government has withdrawn from a number of tasks, which have been allocated to the domain of 'self-governance'.

The increasing involvement of different actor groups in four out of five case studies (the AWB case being an exception) suggests that collaborative governance in AES provision is more than a theoretical construct and has potential in a wide range of situations.

Collaboration in these cases increased not only between groups (e.g. government, farmers, NGOs), but also within groups (in particular between farmers). This development was coupled with an increased involvement of farmers in governance tasks, including the spatial coordination of activities in land management and nature conservation. Those farmer groups which are managing spatial coordination appear to have developed into professional farmer- 
based boundary organisations. Both the increase of collaboration and the professionalization of farmer groups point at the complexity of governance of landscape scale AES. In developing such schemes, an increase of transaction costs should be accepted, especially when this can be justified by improvements in scheme effectiveness. In addition, governments could invest in capacity building, to promote peer-to-peer exchanges and social learning processes between different types of actors, and in this way help to raise the professionalization of farmer groups. Farmer groups, in turn, need to safeguard social capital within the group when growing and professionalising.

We described two stages in the evolution of the five AES case studies, but the reference periods were not necessarily the first period in their evolution, and the new arrangements are unlikely to be the last. However, the way in which experiences from the reference period have been incorporated in the new scheme, and the extent to which learning, monitoring of outcomes and evaluation are organised as part of the governance tasks in the scheme, give an indication of adaptive governance in AES. Although in all case studies, some experiences from the previous scheme were incorporated in the new scheme, there is no evidence that this was based on a comprehensive strategy of learning, monitoring and evaluation. We consider an interdisciplinary (ecological and social) and participatory strategy for learning, monitoring and evaluation (both within farmer groups as well as within the collaborating network as a whole) to be essential for adaptive agri-environmental governance arrangements in general and for landscape scale approaches in particular.

The diversity of governance arrangements outline in the case studies suggest that spatial coordination and collaboration can be arranged in various ways. There is no need to look for a one-size-fits-all, or to use a copy and paste approach to scheme design. Indeed, spatial coordination by a governmental actor, or by a third party working with individual farmers may work well in many areas, and such schemes may be easier to organise than 
complex collaborative governance arrangements (Boulton et al., 2013). In addition, mandatory environmental management may be necessary in some circumstances.

Nevertheless, this article shows that farmer groups can have a substantial role in the governance of AES. As second-hand experiences can be helpful in adaptive learning processes (Barzelay, 2007; Olsson et al., 2004), we are convinced that the case studies in this article will inspire others striving for spatial coordination and collaboration in environmental management schemes. In addition, our findings can be a stimulus for EU Member States to further exploit the possibilities to strengthen the landscape scale approach, e.g. by utilizing the possibility offered in the RDP policy (Regulation (EU) No 1305/2013, article 28, sub-clause 2) to target AES policies to groups of farmers and/or other land-managers.

\section{References}

Appleton, A.F., 2002. How New York City used an ecosystem services strategy carried out through an urban-rural partnership to preserve the pristine quality of its drinking water and save billions of dollars, Forest Trends, Tokyo November 2002.

Armitage, D.R., Plummer, R., Berkes, F., Arthur, R.I., Charles, A.T., Davidson-Hunt, I.J., Diduck, A.P., Doubleday, N.C., Johnson, D.S., Marschke, M., McConney, P., Pinkerton, E.W., Wollenberg, E.K., 2009. Adaptive co-management for social-ecological complexity. Frontiers in Ecology and the Environment 7, 95-102.

Bamière, L., David, M., Vermont, B., 2013. Agri-environmental policies for biodiversity when the spatial pattern of the reserve matters. Ecological Economics 85, 97-104.

Barzelay, M., 2007. Learning from second-hand experience: Methodology for extrapolationoriented case research. Governance 20, 521-543.

Batáry, P., Dicks, L.V., Kleijn, D., Sutherland, W.J., 2015. The role of agri-environment schemes in conservation and environmental management. Conservation Biology 29, 10061016.

Beckmann, V., Eggers, J., Mettepenningen, E., 2009. Deciding how to decide on agrienvironmental schemes: The political economy of subsidiarity, decentralisation and participation in the European Union. Journal of Environmental Planning and Management 52, 689-716. 
Berendse, F., Chamberlain, D., Kleijn, D., Schekkerman, H., 2004. Declining biodiversity in agricultural lanscapes and the effectiveness of agri-environment schemes. Ambio 33, 499502 .

Bijman, J., Hanisch, M., van der Sangen, G., 2014. Shifting control? The changes of internal governance in agricultural cooperatives in the EU. Annals of Public and Cooperative Economics 85, 641-661.

Bodin, Ö., Crona, B.I., 2008. Management of Natural Resources at the Community Level: Exploring the Role of Social Capital and Leadership in a Rural Fishing Community. World Development 36, 2763-2779.

Boulton, A., Lockett, R., Seymour, T., 2013. A review and evaluation of collaborative landscape-scale management initiatives, Scottish Natural Heritage Commissioned Report, Inverness, p. 598.

Burns, F., Eaton, M.A., Barlow, K.E., Beckmann, B.C., Brereton, T., Brooks, D.R., Brown, P.M.J., Al Fulaij, N., Gent, T., Henderson, I., Noble, D.G., Parsons, M., Powney, G.D., Roy, H.E., Stroh, P., Walker, K., Wilkinson, J.W., Wotton, S.R., Gregory, R.D., 2016. Agricultural management and climatic change are the major drivers of biodiversity change in the UK. PLOS ONE 11.

Burton, R.J.F., Schwarz, G., 2013. Result-oriented agri-environmental schemes in Europe and their potential for promoting behavioural change. Land Use Policy 30, 628-641.

Carr, A., Wilkinson, R., 2005. Beyond participation: Boundary organizations as a new space for farmers and scientists to interact. Society and Natural Resources: An International Journal $18,255-265$.

Chartier, O., Cronin, E., Jongeneel, R., Hart, K., Zondag, M.-J., Bocci, M., 2016. Mapping and analysis of the implementation of the CAP. Final Report, Brussels.

de Snoo, G.R., Herzon, I., Staats, H., Burton, R.J., Schindler, S., van Dijk, J., Lokhorst, A.M., Bullock, J.M., Lobley, M., Wrbka, T., Schwarz, G., Musters, C.J.M., 2013. Toward effective nature conservation on farmland: Making farmers matter. Conservation Letters 6, 66-72.

DEFRA, 2005. Higher Level Stewardship Handbook. Terms and conditions and how to apply. DEFRA, London.

Dupraz, P., Latouche, K., Turpin, N., 2009. Threshold effect and co-ordination of agrienvironmental efforts. Journal of Environmental Planning and Management 52, 613-630.

Dutton, A., Edwards-Jones, G., Strachan, R., Macdonald, D.W., 2008. Ecological and social challenges to biodiversity conservation on farmland: Reconnecting habitats on a landscape scale. Mammal Review 38, 205-219.

Dwyer, J., 2014. Policy Integration for Sustainable Agricultural Landscapes: Taking Stock of UK Policy and Practice. Landscape Research 39, 174-189.

EEA, 2015. Biodiversity Briefing. European Environment Agency. 
Eggers, J., Beckmann, V., Mettepenningen, E., Ehlers, M.-H., Hurrelmann, A., Kunz, A., Hagedorn, K., 2007. Analysing Institutional Arrangements for Agri-Environmental Schemes in Europe: ITAES WP4 Final-Report. Humboldt-University, Berlin, Germany.

Emerson, K., Nabatchi, T., Balogh, S., 2012. An integrative framework for collaborative governance. Journal of Public Administration Research and Theory 22, 1-29.

Emery, S.B., Franks, J.R., 2012. The potential for collaborative agri-environment schemes in England: Can a well-designed collaborative approach address farmers' concerns with current schemes? Journal of Rural Studies 28, 218-231.

Fahrig, L., 2003. Effects of Habitat Fragmentation on Biodiversity, Annual Review of Ecology, Evolution, and Systematics, pp. 487-515.

Falconer, K., 2000. Farm-level constraints on agri-environmental scheme participation: a transactional perspective. Journal of Rural Studies 16, 379-394.

Flohre, A., Fischer, C., Aavik, T., Bengtsson, J., Berendse, F., Bommarco, R., Ceryngier, P., Clement, L.W., Dennis, C., Eggers, S., Emmerson, M., Geiger, F., Guerrero, I., Hawro, V., Inchausti, P., Liira, J., Morales, M.B., Oñate, J.J., Pärt, T., Weisser, W.W., Winqvist, C., Thies, C., Tscharntke, T., 2011. Agricultural intensification and biodiversity partitioning in European landscapes comparing plants, carabids, and birds. Ecological Applications 21, 1772-1781.

Folke, C., Hahn, T., Olsson, P., Norberg, J., 2005. Adaptive governance of social-ecological systems. Annual Review of Environment and Resources 30, 441-473.

Franks, J., 2010. Boundary organizations for sustainable land management: The example of Dutch Environmental Co-operatives. Ecological Economics 70, 283-295.

Franks, J.R., 2011. The collective provision of environmental goods: A discussion of contractual issues. Journal of Environmental Planning and Management 54, 637-660.

Franks, J.R., Emery, S.B., 2013. Incentivising collaborative conservation: Lessons from existing environmental Stewardship Scheme options. Land Use Policy 30, 847-862.

Gabriel, D., Sait, S.M., Hodgson, J.A., Schmutz, U., Kunin, W.E., Benton, T.G., 2010. Scale matters: The impact of organic farming on biodiversity at different spatial scales. Ecology Letters 13, 858-869.

Geertsema, W., Opdam, P., Kropff, M.J., 2002. Plant strategies and agricultural landscapes: Survival in spatially and temporally fragmented habitat. Landscape Ecology 17, 263-279.

Hagemann, N., Prager, K., Bartke, S., 2015. Costs of Implementing Agricultural Soil Protection Policies - Insights from Two German Cases. Journal of Environmental Policy and Planning 17, 656-672.

Herzon, I., Helenius, J., 2008. Agricultural drainage ditches, their biological importance and functioning. Biological Conservation 141, 1171-1183.

Hodge, I., 2007. The governance of rural land in a liberalised world. Journal of Agricultural Economics 58, 409-432. 
Hussey, J., Hussey, R., 1997. Business Research. Macmillan Press Ltd., London.

Jongeneel, R., Polman, N., 2014. Farmer groups as a device to ensure the provision of green services in the Netherlands: a political economy perspective, 14th EAAE Congres, Ljubljana.

Jongeneel, R., Polman, N., Slangen, L., 2012. Cost-benefit analysis of the Dutch nature policy: Transaction costs and land market impacts. Land Use Policy 29, 827-836.

Kaswan, M.J., 2014. Developing democracy: cooperatives and democratic theory. International Journal of Urban Sustainable Development 6, 190-205.

Kleijn, D., Berendse, F., Smit, R., Gilissen, N., Smit, J., Brak, B., Groeneveld, R., 2004. Ecological effectiveness of agri-environment schemes in different agricultural landscapes in The Netherlands. Conservation Biology 18, 775-786.

Kleijn, D., Rundlo, M., Scheper, J., Smith, H.G., Tscharntke, T., 2011. Does conservation on farmland contribute to halting the biodiversity decline? Trends in Ecology and Evolution 26, $474-481$.

Kleijn, D., Sutherland, W.J., 2003. How effective are European agri-environment schemes in conserving and promoting biodiversity? Journal of Applied Ecology 40, 947-969.

Kuhfuss, L., Préget, R., Thoyer, S., Hanley, N., 2016. Nudging farmers to enrol land into agrienvironmental schemes: The role of a collective bonus. European Review of Agricultural Economics 43, 609-636.

Mathijs, E., 2003. Social capital and farmers' willingness to adopt countryside stewardship schemes. Outlook on Agriculture 32, 13-16.

Mc Dougall, C., Ram Banjade, M., 2015. Social capital, conflict, and adaptive collaborative governance: Exploring the dialectic. Ecology and Society 20.

McKenzie, A.J., Emery, S.B., Franks, J.R., Whittingham, M.J., 2013. FORUM: Landscapescale conservation: Collaborative agri-environment schemes could benefit both biodiversity and ecosystem services, but will farmers be willing to participate? Journal of Applied Ecology $50,1274-1280$.

Merckx, T., Feber, R.E., Riordan, P., Townsend, M.C., Bourn, N.A.D., Parsons, M.S., Macdonald, D.W., 2009. Optimizing the biodiversity gain from agri-environment schemes. Agriculture, Ecosystems and Environment 130, 177-182.

Mettepenningen, E., Beckmann, V., Eggers, J., 2011. Public transaction costs of agrienvironmental schemes and their determinants-Analysing stakeholders' involvement and perceptions. Ecological Economics 70, 641-650.

Mettepenningen, E., Vandermeulen, V., Delaet, K., Van Huylenbroeck, G., Wailes, E.J., 2013. Investigating the influence of the institutional organisation of agri-environmental schemes on scheme adoption. Land Use Policy 33, 20-30.

Mettepenningen, E., Verspecht, A., van Huylenbroeck, G., 2009. Measuring private transaction costs of European agri-environmental schemes. Journal of Environmental Planning and Management 52, 649-667. 
Mills, J., Gibbon, D., Ingram, J., Reed, M., Short, C., Dwyer, J., 2011. Organising collective action for effective environmental management and social learning in Wales. Journal of Agricultural Education and Extension 17, 69-83.

NAO, 2008. Natural England's Role in Improving Sites of Special Scientific Interest. National Audit Office, London.

OECD, 2013. Providing Agri-environmental Public Goods though Collective Action. OECD Publishing, Paris.

Olsson, P., Folke, C., Berkes, F., 2004. Adaptive comanagement for building resilience in social-ecological systems. Environmental Management 34, 75-90.

Opdam, P., Foppen, R., Vos, C., 2001. Bridging the gap between ecology and spatial planning in landscape ecology. Landscape Ecology 16, 767-779.

Opdam, P., Steingröver, E., Rooij, S.V., 2006. Ecological networks: A spatial concept for multi-actor planning of sustainable landscapes. Landscape and Urban Planning 75, 322-332.

Opdam, P., Verboom, J., Pouwels, R., 2003. Landscape cohesion: An index for the conservation potential of landscapes for biodiversity. 18, 113-126.

Ostrom, E., 1990. Governing The Commons: The Evolution of Institutions for Collective Action. Cambridge University Press, Cambridge.

Polman, N.B.P., 2002. Institutional economics analysis of contractual arrangements; managing wildlife and landscape on Dutch farms. Wageningen Universiteit, Wageningen.

Polman, N.B.P., Slangen, L.H.G., 2008. Institutional design of agri-environmental contracts in the European Union: The role of trust and social capital. NJAS - Wageningen Journal of Life Sciences 55, 413-430.

Polman, N.B.P., Slangen, L.H.G., Van Huylenbroeck, G., 2011. Collective approaches to agri-environmental management, in: Oskam, A.J., Meester, G., Silvis, H.J. (Eds.), EU policy for agriculture, food and rural areas: 2nd revised edition. Wageningen Academic Publishers, Wageningen, pp. 371-376.

Prager, K., 2015a. Agri-environmental collaboratives as bridging organisations in landscape management. Journal of Environmental Management 161, 375-384.

Prager, K., 2015b. Agri-environmental collaboratives for landscape management in Europe. Current Opinion in Environmental Sustainability 12, 59-66.

Prager, K., Freese, J., 2009. Stakeholder involvement in agri-environmental policy making Learning from a local- and a state-level approach in Germany. Journal of environmental management 90, 1154-1167.

Prager, K., Nagel, U.J., 2008. Participatory decision making on agri-environmental programmes: A case study from Sachsen-Anhalt (Germany). Land Use Policy 25, 106-115. 
Prager, K., Reed, M., Scott, A., 2012. Encouraging collaboration for the provision of ecosystem services at a landscape scale-Rethinking agri-environmental payments. Land Use Policy 29, 244-249.

Pretty, J., 2003. Social Capital and the Collective Management of Resources. Science 302, 1912-1914.

Primdahl, J., Kristensen, L.S., 2011. The farmer as a landscape manager: Management roles and change patterns in a Danish region. 111, 107-116.

Schouten, M., Opdam, P., Polman, N., Westerhof, E., 2013. Resilience-based governance in rural landscapes: Experiments with agri-environment schemes using a spatially explicit agentbased model. Land Use Policy 30, 934-943.

Schultz, L., Folke, C., Österblom, H., Olsson, P., 2015. Adaptive governance, ecosystem management, and natural capital. Proceedings of the National Academy of Sciences 112, 7369-7374.

Schusler, T.M., Decker, D.J., Pfeffer, M.J., 2003. Social learning for collaborative natural resource management. Society and Natural Resources 16, 309-326.

Schut, M., Van Paassen, A., Leeuwis, C., 2013. Beyond the research-policy interface. Boundary arrangements at research-stakeholder interfaces in the policy debate on biofuel sustainability in Mozambique. Environmental Science and Policy 27, 91-102.

Seawright, J., Gerring, J., 2008. Case Selection Techniques in Case Study Research: A Menu of Qualitative and Quantitative Options. Political Research Quarterly 61, 294-308.

Shelanski, H.A., Klein, P.G., 1995. Empirical research in transaction cost economics: A review and assessment. Journal of Law, Economics, and Organization 11, 335-361.

Short, C., 2000. Common land and ELMS: A need for policy innovation in England and Wales. Land Use Policy 17, 121-133.

Short, C., Winter, M., 1999. The problem of common land: Towards stakeholder governance. Journal of Environmental Planning and Management 42, 613-630.

Short, S., Waldon, J., 2013. The apportionment of agri-environment scheme monies on common land in England. Report to the European Forum for Nature Conservation and Pastoralism Foundation for Common Land, Penrith.

Steingröver, E.G., Geertsema, W., van Wingerden, W.K.R.E., 2010. Designing agricultural landscapes for natural pest control: A transdisciplinary approach in the Hoeksche Waard (The Netherlands). Landscape Ecology 25, 825-838.

Terwan, P., Rozendaal, W., 2014. Vergroenen van de landbouw doe je beter samen. Oefenen met een collectief leveringsstelsel voor vergroening en groenblauwe diensten - Lessen uit de vier GLB-pilots 2011-2014 Agrarische Natuurvereniging Oost Groningen, Vereniging Noardlike Fryske Wâlden, Agrarische natuur- en landschapsvereniging Water, Land \& Dijken, Stichting WCL Winterswijk, Utrecht. 
Van Teeffelen, A.A., Vos, C., Jochem, R., Baveco, J., Meeuwsen, H., Hilbers, J., 2015. Is green infrastructure an effective climate adaptation strategy for conserving biodiversity? A case study with the great crested newt. Landscape Ecology 30, 937-954.

Weber, A., 2015. Implementing EU co-financed agri-environmental schemes: Effects on administrative transaction costs in a regional grassland extensification scheme. Land Use Policy 42, 183-193.

Westerink, J., Melman, T.C.P., Schrijver, R.A.M., 2015. Scale and self-governance in agrienvironment schemes: experiences with two alternative approaches in the Netherlands. Journal of Environmental Planning and Management 58, 1490-1508.

Westerink, J., Opdam, P., van Rooij, S., Steingröver, E., 2017. Landscape services as boundary concept in landscape governance: Building social capital in collaboration and adapting the landscape. Land Use Policy 60, 408-418.

Wolz, A., Fritzsch, J., Buchenrieder, G., Nedoborovskyy, A., 2010. Does cooperation pay? the role of social capital among household plot farmers in Ukraine. South East European Journal of Economics and Business 5, 55-64. 


\section{Annex A: Tables with distribution governance tasks in the case studies of landscape approach agri-environment schemes (AES)}

This appendix summarizes the distribution of governance tasks among actors in the case studies. Actors performing part of the governance of the AES are categorized as governmental, group of farmers or third parties. Governmental actors include local and regional tiers. The other private (third) parties include (external) parties such as NGOs, consultants, and volunteer (groups). The cases are presented separately in five tables: (A1) Arguenon water basin (AWD), France; (A2) Agrobeheercentrum (Eco²), Flanders, Belgium; (A3) Supplement for Group Applications (HR8), England, United Kingdom; (A4) Stiftung Rheinische Kulturlandschaft (SRK), Germany; and (A5) Water Land \& Dijken (WLD), the Netherlands. In every case the reference situation is in the top cell (light grey) and the alternative, new situation in the bottom cell. If a task is performed by an actor category it is ticked with " $\sqrt{ }$ " and if a task is not performed by an actor category it is denoted with "_-“. 
Table A1: Table with governance tasks in the French Arguenon case in the previous situation (top cells per task): before establishment of last policy change, compared to the current situation (bottom cells per task)*

\begin{tabular}{|c|c|c|c|}
\hline \multirow[b]{2}{*}{ Governance tasks } & \multirow{2}{*}{$\begin{array}{l}\text { Government } \\
\text { (public) }\end{array}$} & \multicolumn{2}{|c|}{ Private parties } \\
\hline & & Farmer group & Third parties \\
\hline \multirow[t]{2}{*}{$\begin{array}{l}\text { Goal setting at } \\
\text { landscape level }\end{array}$} & $\begin{array}{l}\sqrt{ } \text { Nuts3, Nuts5 } \\
\sqrt{ } \text { State, Côte d'Armor (regional } \\
\text { council), Town }\end{array}$ & $\sqrt{ }$ Farmers local group & $\begin{array}{c}\sqrt{ } \text { Farmer group, (nitrate levels in } \\
\text { water }\end{array}$ \\
\hline & $\sqrt{ }$ State authorities take the leadership & $\begin{array}{l}\text { - Local farmer representatives are } \\
\text { consulted }\end{array}$ & $\sqrt{ }$ Water agency \\
\hline \multirow[t]{2}{*}{ Design of scheme } & $\begin{array}{c}\sqrt{ } \text { Government, Nuts3 } \\
\sqrt{ } \text { State, Côte d'Armor (regional } \\
\text { council), Town, Water agency, local } \\
\text { water association Arguenon-Penthièvre }\end{array}$ & $\sqrt{ }$ Farmer group & $\begin{array}{c}\sqrt{ } \text { Chamber of Agriculture (farmland } \\
\text { office) }\end{array}$ \\
\hline & $\sqrt{ }$ State authorities take the leadership & $\begin{array}{l}\text { - Local farmer representatives are } \\
\text { consulted }\end{array}$ & - \\
\hline \multirow[t]{2}{*}{$\begin{array}{l}\text { Design of on-farm } \\
\text { measures }\end{array}$} & $\begin{array}{c}\sqrt{ } \text { Government, Nuts3 } \\
\sqrt{ } \text { State, Côte d'Armor (regional council) }\end{array}$ & $\sqrt{ }$ Local farmer group & $\sqrt{ }$ Chamber of Agriculture \\
\hline & $\begin{array}{l}\sqrt{ } \text { Water European directive water } \\
\text { agency, local water association } \\
\text { Arguenon -Penthièvre }\end{array}$ & $\begin{array}{l}\text { - Local farmer representatives are } \\
\text { consulted }\end{array}$ & $\sqrt{ }$ Unchanged \\
\hline \multirow[t]{2}{*}{ Spatial coordination } & - & - & - \\
\hline & $\begin{array}{c}\sqrt{\text { Leadership by State authorities, Nuts3 } 3} \\
\text { Côte d'Armor region, towns and water } \\
\text { agency }\end{array}$ & $\begin{array}{l}\sqrt{ } \text { Local farmer representatives are } \\
\text { consulted in the whole watershed }\end{array}$ & $\begin{array}{l}\sqrt{ } \text { Chamber of Agriculture (farmland } \\
\text { office) }\end{array}$ \\
\hline \multirow[t]{2}{*}{ Recruiting participants } & - & - & $\begin{array}{c}\sqrt{ } \text { Chamber of Agriculture (farmland } \\
\text { office) }\end{array}$ \\
\hline & $\sqrt{ }$ State, Town & - & $\begin{array}{c}\sqrt{ } \text { SBAFER, NUTS2 regional rural } \\
\text { land office }\end{array}$ \\
\hline \multirow[t]{2}{*}{$\begin{array}{l}\text { Contracting individual } \\
\text { farmers }\end{array}$} & $\begin{array}{c}\sqrt{ } \text { Government, Département, water } \\
\text { agency }\end{array}$ & - & $\begin{array}{c}\sqrt{ } \text { Chamber of Agriculture (farmland } \\
\text { office) }\end{array}$ \\
\hline & $\sqrt{ }$ Unchanged & - & $\begin{array}{c}\sqrt{ } \text { Town community, expended } \\
\text { watershed, SBAFER, Brittany land } \\
\text { regulator }\end{array}$ \\
\hline \multirow[t]{2}{*}{ Extension } & $\sqrt{ }$ Water agency, Côte d'Armor (region) & - & $\begin{array}{c}\sqrt{ } \text { Chamber of Agriculture (farmland } \\
\text { office) }\end{array}$ \\
\hline & $\begin{array}{l}\sqrt{ } \text { Town community, expanded } \\
\text { watershed }\end{array}$ & $\sqrt{ }$ Farmers in an expanded watershed & - \\
\hline \multirow[t]{2}{*}{$\begin{array}{l}\text { Organising exchange } \\
\text { and learning }\end{array}$} & $\sqrt{ }$ EU funds paying agency (ASP) & - & $\begin{array}{c}\sqrt{ } \text { Chamber of Agriculture (farmland } \\
\text { office) }\end{array}$ \\
\hline & $\sqrt{ }$ Unchanged & $\sqrt{\text { Local farmer group }}$ & $\begin{array}{c}\sqrt{ } \text { Chamber of Agriculture (farmland } \\
\text { office), (SBAFER, Brittany land } \\
\text { regulator) }\end{array}$ \\
\hline \multirow[t]{2}{*}{ Monitoring of results } & $\begin{array}{l}\sqrt{ } \text { Government, Water agency, Côte } \\
\text { d'Armor (region), EU funds paying } \\
\text { agency (ASP) } \\
\end{array}$ & $\sqrt{ }$ Farmer group & $=$ \\
\hline & $\sqrt{ }$ Unchanged & $\sqrt{ }$ Unchanged & $=$ \\
\hline \multirow[t]{2}{*}{ Control } & $\begin{array}{l}\sqrt{ } \text { EU funds paying agency (ASP), Water } \\
\text { agency, Côte d'Armor (region), because } \\
\text { these organizations fund action } \\
\text { programs, therefore they also control. }\end{array}$ & - & - \\
\hline & $\sqrt{ }$ New perimeter control & - & - \\
\hline \multirow[t]{2}{*}{ Payment } & $\begin{array}{l}\sqrt{ } \text { Agence de Service et de Paiement } \\
\text { (ASP), Water agency, Côte d'Armor } \\
\text { (region) }\end{array}$ & - & - \\
\hline & $\sqrt{ }$ Unchanged & - & - \\
\hline \multirow[t]{2}{*}{ Evaluation } & $\begin{array}{c}\sqrt{\text { Government, EU funds paying agency }} \\
\text { (ASP), Water Agency, Côte d'Armor } \\
\text { (regional council) }\end{array}$ & - & $\begin{array}{l}\sqrt{ } \text { Chamber of Agriculture (farm } \\
\text { land office) }\end{array}$ \\
\hline & $\sqrt{ }$ Unchanged & - & $\begin{array}{l}\sqrt{\text { Town community, expanded }} \\
\text { watershed }\end{array}$ \\
\hline
\end{tabular}

* Chamber of Agriculture: Joint organization: agricultural policy in France is co-managed between the administration (central [State] and decentralized [representation of the central government in the regions and the departments] and agricultural professions represented by the majority unions. Most management agencies, animation and financing fall under this principle: from a legal point of view, they are public organization and private, however we classify the public organization in a private category because report to a specific operation that be confused with that of joint structure. 
Document de travail Eureval C3E, décembre 2012

Arrêté préfectoral déclarant d'utilité publique l'instauration, autour de la retenue de la Ville Hatte sur l'Arguenon, des périmètres de protection réglementaire et instituant des servitudes pour le compte du Département des Côtes-d'Armor. Janvier 2008.

Conseil général des Côtes-d'Armor (2007). Enquête d'utilité publique. Révision de la protection autour de la retenue d'eau sur l'Arguenon. Prise d'eau de la Ville Hatte à Pléven.

Conseil général des Côtes-d'Armor (2005); L'alimentation en eau potable dans les Côtes-d'Armor. Protection des points d'eau publics: le protocole d'accord. 
Table A2: Table with governance tasks for $\mathrm{Eco}^{2}$ case in the previous situation before establishment of Eco ${ }^{2}$ (top cells per task), compared to the current situation (before 2016) with changed role of $\mathrm{Eco}^{2}$ (bottom cells per task).

\begin{tabular}{|c|c|c|c|}
\hline \multirow[b]{2}{*}{ Governance tasks } & \multirow{2}{*}{$\begin{array}{l}\text { Government } \\
\text { (public) }\end{array}$} & \multicolumn{2}{|c|}{ Private parties } \\
\hline & & Farmer group Eco ${ }^{2}$ & Third parties \\
\hline \multirow[t]{2}{*}{$\begin{array}{l}\text { Goal setting at } \\
\text { landscape level }\end{array}$} & $\begin{array}{l}\sqrt{ } \text { Flemish government (designating areas } \\
\text { and conservation targets) }\end{array}$ & 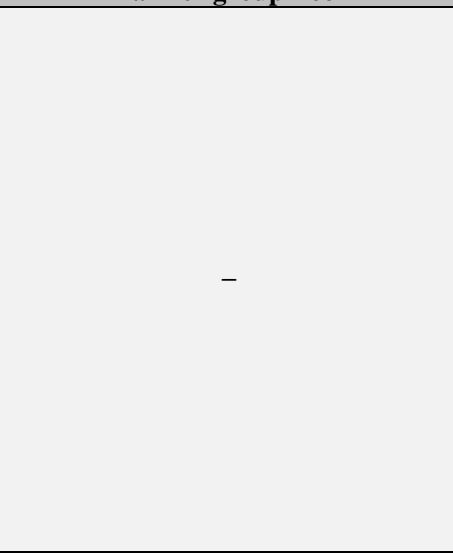 & 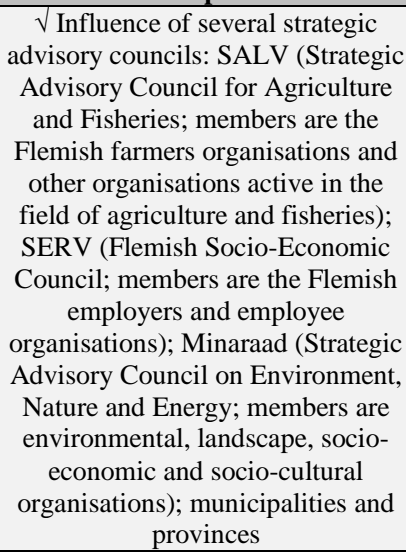 \\
\hline & $\begin{array}{c}\sqrt{ } \text { The } \mathrm{Eco}^{2} \text { has an influence on goal } \\
\text { setting regarding AEMs and BOs through } \\
\text { the representation of its members in } \\
\text { advisory committees such as SALV.Eco } \\
\text { however, has most influence on goal } \\
\text { setting in local agri-environmental projects } \\
\text { outside of AEMs (agri-environment } \\
\text { measures) and BOs (management } \\
\text { agreements) }\end{array}$ & - & $\sqrt{ }$ Unchanged \\
\hline \multirow[t]{2}{*}{ Design of schemes } & $\begin{array}{l}\text { For AEMs: Department of Agriculture } \\
\text { and Fisheries- Division of Sustainable } \\
\text { Agricultural Development; For BOs: } \\
\text { Flemish Land Agency }\end{array}$ & - & $\begin{array}{l}\sqrt{ } \text { Advice from SALV, SERV, } \\
\text { Minaraad }\end{array}$ \\
\hline & $\sqrt{\text { See goal setting }}$ & - & $\sqrt{\text { Unchanged }}$ \\
\hline \multirow[t]{2}{*}{$\begin{array}{l}\text { Design of on-farm } \\
\text { measures }\end{array}$} & $\begin{array}{c}\sqrt{\text { For AEMs: Department of Agriculture }} \\
\text { and Fisheries- Division of Sustainable } \\
\text { Agricultural Development; For BOs: } \\
\text { Flemish Land Agency }\end{array}$ & - & $\begin{array}{c}\sqrt{ } \text { Advice from SALV, SERV, } \\
\text { Minaraad }\end{array}$ \\
\hline & $\sqrt{\text { See goal setting }}$ & - & $\sqrt{\text { Unchanged }}$ \\
\hline \multirow[t]{2}{*}{ Spatial coordination } & $\begin{array}{l}\sqrt{ } \text { AEMs are applicable to Flanders as a } \\
\text { whole; Some BOs are targeted to specific } \\
\text { areas; and Farm planners of the VLM } \\
\text { strategically approach farmers to convince } \\
\text { them to participate, to ensure a landscape } \\
\text { approach and increase the environmental } \\
\text { effectiveness of the AEMs and BOs }\end{array}$ & - & - \\
\hline & $\sqrt{ }$ Unchanged & $\begin{array}{l}\sqrt{ } \text { Together with the farm planners, } \\
\text { regional coordinators of the Eco }{ }^{2} \text { try to } \\
\text { achieve spatial coordination of AEMs } \\
\text { and BOs }\end{array}$ & - \\
\hline \multirow[t]{2}{*}{ Recruiting participants } & $\begin{array}{l}\sqrt{ } \text { Managing authorities, through websites, } \\
\text { folders, etc. and Farm planners of the } \\
\text { VLM play an important role in convincing } \\
\text { farmers to participate in agri- } \\
\text { environmental management and also help } \\
\text { them with the application procedure }\end{array}$ & - & $\begin{array}{l}\sqrt{ } \text { Flemish Rural Network: groups } \\
\text { all organisations and government } \\
\text { bodies involved in the PDPO; one } \\
\text { of its tasks is providing info on the } \\
\text { PDPO; and Farmers organisations }\end{array}$ \\
\hline & $\sqrt{ }$ Unchanged & $\begin{array}{l}\sqrt{ } \text { Done by the regional coordinators of } \\
\text { the Eco } \mathrm{Ec}^{2} \text { and regional coordinators } \\
\text { apply for agri-environmental projects } \\
\text { for their ABGs, outside of the AEMs } \\
\text { and BOs }\end{array}$ & $\sqrt{ }$ Unchanged \\
\hline \multirow[t]{2}{*}{$\begin{array}{l}\text { Contracting individual } \\
\text { farmers }\end{array}$} & $\begin{array}{c}\sqrt{ } \text { Farmers can apply for all their subsidies } \\
\text { through a collective (online) application } \\
\text { ('verzamelaanvraag'). }\end{array}$ & - & - \\
\hline & $\sqrt{ }$ Unchanged & - & $\begin{array}{l}\sqrt{ } \text { For projects, this is done through } \\
\text { the vehicle AgroAanneming }\end{array}$ \\
\hline \multirow[t]{2}{*}{ Extension } & $\begin{array}{c}\sqrt{\text { Farm planners of the VLM; Managing }} \\
\text { authorities of AEMs and BOs; and } \\
\text { Provincial and municipal agricultural } \\
\text { counters }\end{array}$ & - & - \\
\hline & $\sqrt{ }$ Unchanged & $\begin{array}{c}\sqrt{\text { Regional coordinators advise their }} \\
\text { ABGs on agri-environmental } \\
\text { management }\end{array}$ & - \\
\hline
\end{tabular}




\begin{tabular}{|c|c|c|c|}
\hline \multirow[b]{2}{*}{ Governance tasks } & \multirow{2}{*}{$\begin{array}{c}\text { Government } \\
\text { (public) }\end{array}$} & \multicolumn{2}{|c|}{ Private parties } \\
\hline & & Farmer group Eco ${ }^{2}$ & Third parties \\
\hline \multirow[t]{2}{*}{$\begin{array}{l}\text { Organising exchange } \\
\text { and learning }\end{array}$} & - & - & $\sqrt{ }$ Farmers organisations \\
\hline & - & $\begin{array}{l}\sqrt{ } \text { The Eco }^{2} \text { regularly organises courses } \\
\text { on agri-environmental management and } \\
\text { organises exchange between ABGs (also } \\
\text { internationally). }\end{array}$ & $\sqrt{ }$ Unchanged \\
\hline \multirow[t]{2}{*}{ Monitoring of results } & $\begin{array}{l}\sqrt{ } \text { By the managing authorities, } \\
\text { coordinated by the CCEP (Coordinating } \\
\text { Cell for European Rural Policy); and } \\
\text { Executive Committee } \\
\text { ('Uitvoeringscomité): members are all } \\
\text { government bodies involved in the PDPO; } \\
\text { they meet regularly to discuss progress. }\end{array}$ & 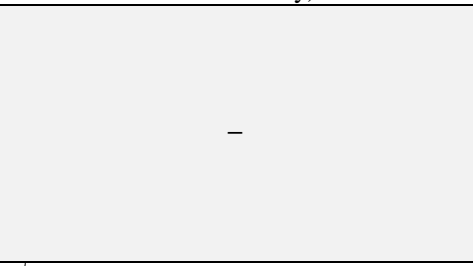 & $\begin{array}{c}\sqrt{\text { Supervisory Committee }} \\
\text { ('Toezichtscomité'): members are } \\
\text { representatives from the Executive } \\
\text { Committee, different levels of } \\
\text { government (including EU and } \\
\text { municipal levels), SALV, SERV, } \\
\text { Minaraad; evaluate progress and } \\
\text { realisation of objectives. }\end{array}$ \\
\hline & $\sqrt{ }$ Unchanged & $\begin{array}{l}\sqrt{ } \text { Regional coordinators closely monitor } \\
\text { the activities of their ABGs, especially } \\
\text { at the beginning of projects; The Eco }{ }^{2} \text { is } \\
\text { planning to engage in a research project } \\
\text { that will investigate alternative } \\
\text { monitoring schemes (by volunteers, } \\
\text { farmers themselves, local organisations, } \\
\text { etc.) }\end{array}$ & $\sqrt{ }$ Unchanged \\
\hline \multirow[t]{2}{*}{ Control } & $\begin{array}{l}\sqrt{ } \text { Agency for Agriculture and Fisheries } \\
\text { (Flemish level, payment authority) }\end{array}$ & - & - \\
\hline & $\sqrt{ }$ Unchanged & - & - \\
\hline \multirow[t]{2}{*}{ Payment } & $\begin{array}{l}\sqrt{ } \text { Agency for Agriculture and Fisheries } \\
\text { (Flemish level, payment authority) }\end{array}$ & - & - \\
\hline & $\sqrt{ }$ Unchanged & $\begin{array}{l}\sqrt{ } \text { Still individual payments for AEMs } \\
\text { and BOs, which are then redistributed } \\
\text { by the Eco among the farmers of the } \\
\text { ABG, AgroAanneming is again used as } \\
\text { a vehicle; Payments for project work go } \\
\text { through the Eco } \text { Eco }^{2} \text { and AgroAanneming. }\end{array}$ & - \\
\hline \multirow[t]{2}{*}{ Evaluation } & $\begin{array}{l}\sqrt{\text { Department of Agriculture and }} \\
\text { Fisheries, Division of Monitoring and } \\
\text { Studies: they are responsible, but the } \\
\text { actual evaluation is done by an external } \\
\text { consortium of researchers. }\end{array}$ & - & - \\
\hline & $\sqrt{ }$ Unchanged & $\begin{array}{c}\sqrt{ } \text { The operations of the } \mathrm{Eco}^{2} \text { and its } \\
\text { ABGs are evaluated by its Management } \\
\text { Board }\end{array}$ & - \\
\hline
\end{tabular}


Table A3: Table with governance tasks in the previous situation (top cells per task): stand-alone Wildlife Enhancement Scheme agreements (WES) and Countryside Stewardship Scheme top-up payments for AES agreements covering upland commons (CSS+WES, 1994-2008) compared to the current situation (bottom cells per task): collaborative AES option HR8 on upland commons agreements: 2005 to 2015.

\begin{tabular}{|c|c|c|c|}
\hline \multirow[b]{2}{*}{ Governance tasks } & \multirow{2}{*}{$\begin{array}{l}\text { Government } \\
\text { (public) }\end{array}$} & \multicolumn{2}{|c|}{ Private parties } \\
\hline & & Farmer group & Third parties \\
\hline \multirow[t]{2}{*}{$\begin{array}{l}\text { Goal setting at } \\
\text { landscape level }\end{array}$} & $\begin{array}{l}\sqrt{ } \text { Targeted at high nature value areas, } \\
\text { including common land (SSSIs) }\end{array}$ & - & - \\
\hline & $\begin{array}{l}\sqrt{ } \text { Generally follows widespread } \\
\text { consultation, and based on NE } \\
\text { experience and knowledge bank. }\end{array}$ & $\sqrt{ }$ Involved in consultation & $\begin{array}{l}\sqrt{ } \text { Various parties involved in } \\
\text { consultation }\end{array}$ \\
\hline \multirow[t]{2}{*}{ Design of scheme } & $\begin{array}{c}\sqrt{ } \text { NE designed WES to maintain and } \\
\text { enhance nature conservation entered into } \\
\text { the scheme, and to augment CSS } \\
\text { agreements. }\end{array}$ & - & - \\
\hline & $\begin{array}{l}\sqrt{ } \text { Consultation combined with NE } \\
\text { knowledge }\end{array}$ & $\sqrt{ }$ Involved in consultation & $\sqrt{ }$ Involved in consultation \\
\hline \multirow[t]{2}{*}{$\begin{array}{l}\text { Design of on-farm } \\
\text { measures (i.e. } \\
\text { environmental } \\
\text { management options) }\end{array}$} & $\begin{array}{c}\sqrt{ } \text { Environmental measures vary between } \\
\text { agreements, depending on targeted } \\
\text { habitat type. }\end{array}$ & $\begin{array}{l}\sqrt{ } \text { Management plan agreed in discussions } \\
\text { with farmers, special management may be } \\
\text { required at specific sites. Local } \\
\text { adjustment to management prescriptions } \\
\text { allowed "with full justification". }\end{array}$ & - \\
\hline & $\begin{array}{l}\sqrt{ } \text { Periodic reforms to existing options } \\
\text { after consultation. }\end{array}$ & - & $\begin{array}{l}\sqrt{ } \text { New environmental } \\
\text { management options often trialled } \\
\text { before being introduced. }\end{array}$ \\
\hline \multirow[t]{2}{*}{ Spatial coordination } & $\begin{array}{l}\sqrt{ } \text { All participating farmers in the same } \\
\text { WES+CSS were offered the same } \\
\text { management prescriptions options. }\end{array}$ & - & - \\
\hline & $\begin{array}{l}\sqrt{ } \text { Through targeting farmers managing } \\
\text { (part of) the same feature. }\end{array}$ & $\sqrt{ }$ Through joint plans & - \\
\hline \multirow[t]{2}{*}{ Recruiting participants } & $\begin{array}{l}\sqrt{ } \text { NE devolved recruitment to their } \\
\text { Local Teams. National Park authorities } \\
\text { (government bodies) may become } \\
\text { involved as and where appropriate. }\end{array}$ & - & - \\
\hline & $\sqrt{ } \mathrm{NE}$ & - & $\begin{array}{l}\sqrt{\text { National Park Authorities, }} \\
\text { landlords and/or conservation } \\
\text { NGOs may be involved, especially } \\
\text { where no Commoners/Grazing } \\
\text { Association exists. }\end{array}$ \\
\hline \multirow[t]{2}{*}{$\begin{array}{l}\text { Contracting individual } \\
\text { farmers }\end{array}$} & $\begin{array}{l}\text { V NE signed agreements on common } \\
\text { land with a representative of the } \\
\text { participants. The actual management } \\
\text { prescriptions were agreed on an } \\
\text { individual basis. }\end{array}$ & - & - \\
\hline & $\begin{array}{c}\sqrt{\text { External contract between } \mathrm{NE} \text { and an }} \\
\text { individual representative acting on } \\
\text { behalf of all stakeholders. }\end{array}$ & $\begin{array}{l}\sqrt{ } \text { Supported by an internal agreement } \\
\text { between stakeholders. }\end{array}$ & $\begin{array}{c}\sqrt{ } \text { Internal agreement involves land } \\
\text { owners, which may be non- } \\
\text { farmers. }\end{array}$ \\
\hline \multirow[t]{2}{*}{ Extension } & - & - & - \\
\hline & - & - & - \\
\hline \multirow[t]{2}{*}{$\begin{array}{l}\text { Organising exchange } \\
\text { and learning }\end{array}$} & $\begin{array}{l}\sqrt{\text { Farmers had to keep records of all }} \\
\text { management activities. These records } \\
\text { were used to monitor results, inform } \\
\text { future decisions and to facilitate the } \\
\text { partnership. }\end{array}$ & - & - \\
\hline & $\begin{array}{l}\text { - Farmers need to keep records of all } \\
\text { management activities. No formal, } \\
\text { organised exchange and learning. }\end{array}$ & - & - \\
\hline \multirow[t]{2}{*}{ Monitoring of results } & $\begin{array}{c}\sqrt{\text { Annual visits from EN/NE staff. }} \\
\text { Biological monitoring in visits by NE } \\
\text { Local Teams, who identify necessary } \\
\text { management changes. }\end{array}$ & - & - \\
\hline & $\begin{array}{l}\sqrt{ } \text { HR8 monitored through records of } \\
\text { meetings. HLS agreements have pre- } \\
\text { specified Indicators of Success (IoS). } \\
\text { Field based evaluations. }\end{array}$ & $\begin{array}{l}\sqrt{ } \text { HR8 monitored through records of } \\
\text { meetings }\end{array}$ & - \\
\hline \multirow[t]{2}{*}{ Control } & $\begin{array}{c}\sqrt{\text { No payments released before results of }} \\
\text { annual monitoring visit. Control in } \\
\text { accordance with EU regulations. }\end{array}$ & - & - \\
\hline & $\begin{array}{l}\sqrt{ } \text { Payment only when IoS have been } \\
\text { achieved }\end{array}$ & - & - \\
\hline Payment & $\begin{array}{l}\sqrt{ } \text { Annual, standard (flat rate) payments } \\
\text { for each management prescription were }\end{array}$ & - & - \\
\hline
\end{tabular}




\begin{tabular}{|c|c|c|c|}
\hline \multirow[b]{2}{*}{ Governance tasks } & \multirow{2}{*}{$\begin{array}{c}\text { Government } \\
\text { (public) }\end{array}$} & \multicolumn{2}{|c|}{ Private parties } \\
\hline & & Farmer group & Third parties \\
\hline & $\begin{array}{l}\text { derived from a "model farm". Payment } \\
\text { for capital work on a one-off basis. }\end{array}$ & & \\
\hline & $\begin{array}{l}\sqrt{ } \text { HR8 is a flat rate/ha payment. A single } \\
\text { payments made to each group, twice a } \\
\text { year. }\end{array}$ & $\begin{array}{l}\sqrt{ } \text { Distribution among group members: } \\
\text { stakeholder's share depends on the terms } \\
\text { in the internal agreement. }\end{array}$ & - \\
\hline \multirow[t]{2}{*}{ Evaluation } & $\begin{array}{c}\sqrt{ } \text { Lessons learned extended the existing } \\
\text { knowledge base within EN/NE }\end{array}$ & - & - \\
\hline & $\begin{array}{c}\sqrt{ } \text { HLS: no HR8 option specific } \\
\text { evaluation. }\end{array}$ & - & - \\
\hline
\end{tabular}


Table A4: Table with governance tasks for SRK case in the previous situation before establishment of SRK (top cells per task), compared to the current situation with Stiftung Rheinische Kulturlandschaft initiating and coordinating projects (bottom cells per task).

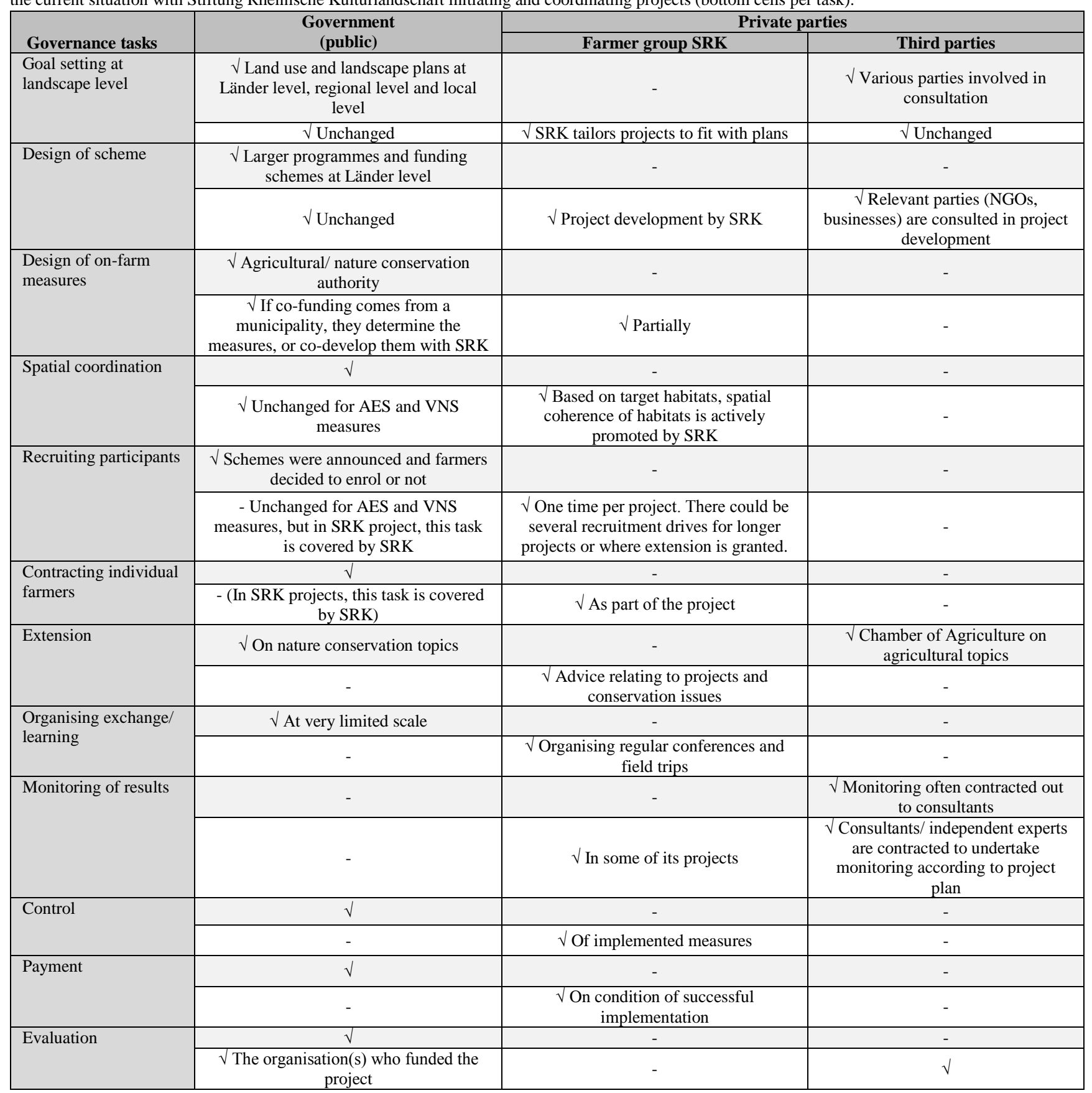

Legend: VNS = Vertragsnaturschutz (conservation agreements) with funding according to Länder directives 
Table A5: Table with governance tasks in the WLD case in the previous situation (top cells per task): before establishment of last policy change in the agri-environment scheme, compared to the current situation (bottom cells per task)

\begin{tabular}{|c|c|c|c|}
\hline \multirow[b]{2}{*}{ Governance tasks } & \multirow{2}{*}{$\begin{array}{c}\text { Government } \\
\text { (public) }\end{array}$} & \multicolumn{2}{|c|}{ Private parties } \\
\hline & & Farmer group WLD & Third parties \\
\hline \multirow[t]{2}{*}{$\begin{array}{l}\text { Goal setting at } \\
\text { landscape level }\end{array}$} & $\begin{array}{l}\sqrt{ } \text { Provincial government (designating } \\
\text { areas and conservation targets) }\end{array}$ & - & $\sqrt{ }$ Landschap Noord-Holland (LNH) \\
\hline & $\begin{array}{l}\sqrt{ } \text { The province designs area plans (goal } \\
\text { setting }\end{array}$ & - & $\sqrt{ }$ Unchanged \\
\hline \multirow[t]{2}{*}{ Design of scheme } & $\sqrt{ }$ National government. & - & - \\
\hline & $\begin{array}{l}\sqrt{ } \text { The national government is } \\
\text { responsible for legal setting. Regional } \\
\text { water board (e.g. ditches); Provinces } \\
\text { have played a role in developing the } \\
\text { Catalogue Green and Blue services }\end{array}$ & $\begin{array}{l}\sqrt{ } \text { WLD (together with other farmer } \\
\text { groups within a national organisation } \\
\text { called Foundation Collective } \\
\text { Agricultural Nature Management, } \\
\text { SCAN). SCAN played an important } \\
\text { role in setting up the governance system } \\
\text { (e.g. certification of working methods } \\
\text { of collectives) and was subsidized by } \\
\text { the Dutch government. }\end{array}$ & $\sqrt{ }$ Experts were hired as consultant \\
\hline \multirow[t]{2}{*}{$\begin{array}{l}\text { Design of on-farm } \\
\text { measures }\end{array}$} & $\begin{array}{l}\sqrt{ } \text { Provincial governments and central } \\
\text { state; and Farmers have had an advising } \\
\text { role in design of measures. }\end{array}$ & ( & $\begin{array}{l}\sqrt{ } \text { Experts were often involved as } \\
\text { advisor }\end{array}$ \\
\hline & $\begin{array}{l}\text { - Province negotiates with WLD based } \\
\text { on WLD proposal }\end{array}$ & $\begin{array}{l}\sqrt{ } \text { WLD is responsible for developing } \\
\text { measures; They are taken from the } \\
\text { Catalogue Green and Blue services or } \\
\text { adapted from it (tailor-made). }\end{array}$ & $\begin{array}{l}\sqrt{ } \text { Experts are often involved as } \\
\text { advisor }\end{array}$ \\
\hline \multirow[t]{2}{*}{ Spatial coordination } & $\sqrt{ }$ & - & - \\
\hline & - & $\sqrt{ }$ WLD & - \\
\hline \multirow[t]{2}{*}{ Recruiting participants } & $\sqrt{ }$ Official role & $\sqrt{ }$ Informal role & - \\
\hline & - & $\sqrt{ }$ WLD & - \\
\hline \multirow[t]{2}{*}{$\begin{array}{l}\text { Contracting individual } \\
\text { farmers }\end{array}$} & $\begin{array}{l}\sqrt{\text { Province after a check by the Dutch }} \\
\text { paying agency whether individual } \\
\text { applications for agri-environmental } \\
\text { contracts were in compliance with the } \\
\text { regional management plan. }\end{array}$ & - & -- \\
\hline & - & $\sqrt{ }$ WLD & - \\
\hline \multirow[t]{2}{*}{ Extension } & - & $\begin{array}{l}\sqrt{ } \text { WLD has field coordinators who are } \\
\text { contact points (communication) } \& \\
\text { advisors for farmers }\end{array}$ & $\begin{array}{l}\sqrt{ } \mathrm{LNH} \text { trains volunteers for } \\
\text { monitoring }\end{array}$ \\
\hline & - & $\sqrt{ }$ unchanged & $\sqrt{ }$ unchanged \\
\hline \multirow[t]{2}{*}{$\begin{array}{l}\text { Organising exchange } \\
\text { and learning }\end{array}$} & - & $\begin{array}{c}\sqrt{ } \text { WLD: Newsletters, meetings, and } \\
\text { education }\end{array}$ & $\begin{array}{l}\sqrt{\text { Local environmental groups }} \\
\text { discuss best management practices } \\
\text { for grassland use and predation } \\
\text { control }\end{array}$ \\
\hline & - & $\sqrt{ }$ unchanged & - \\
\hline \multirow[t]{2}{*}{ Monitoring of results } & $\begin{array}{l}\sqrt{ } \text { The province is responsible for the } \\
\text { monitoring of conservation results }\end{array}$ & $\begin{array}{l}\sqrt{\text { Volunteers: about } 650 \text { volunteers }} \\
\text { assist the farmers in tracing, marking, } \\
\text { registering and protecting the nests } \\
\text { (volunteers are shared with LNH) }\end{array}$ & - \\
\hline & - & $\begin{array}{l}\sqrt{ } \text { WLD takes responsibility for the } \\
\text { monitoring of conservation results with } \\
\text { the aid of volunteers and consultancies }\end{array}$ & $\begin{array}{l}\text { - Consultancies are involved, but } \\
\text { not responsible }\end{array}$ \\
\hline \multirow[t]{2}{*}{ Control } & $\begin{array}{c}\sqrt{\text { Food and Consumer Product Safety }} \\
\text { Authority of individual farmers: } \\
\text { Scheme enforcement by selective field } \\
\text { inspections }\end{array}$ & $\begin{array}{c}\text { - No official role, but WLD has a } \\
\text { committee that checks if farmers } \\
\text { comply with contract }\end{array}$ & - \\
\hline & $\begin{array}{l}\text { - National Food and Consumer Product } \\
\text { Safety Authority controls farmer group }\end{array}$ & $\begin{array}{l}\sqrt{ } \text { WLD is now officially responsible for } \\
\text { control of individual farmers }\end{array}$ & - \\
\hline Payment to farmers & $\begin{array}{l}\sqrt{ } \text { Dutch paying agency paid individual } \\
\text { farmers. }\end{array}$ & $\begin{array}{l}\sqrt{ } \text { Unlike most AECs, WLD made } \\
\text { individual contracts with participating } \\
\text { farmers for redistributing money that } \\
\text { they had received from the Dutch } \\
\text { paying agency (to have results based } \\
\text { payments) }\end{array}$ & - \\
\hline
\end{tabular}




\begin{tabular}{|c|c|c|c|}
\hline \multirow{3}{*}{ Governance tasks } & \multirow{2}{*}{$\begin{array}{c}\text { Government } \\
\text { (public) }\end{array}$} & \multicolumn{2}{|c|}{ Private parties } \\
\hline & & Farmer group WLD & Third parties \\
\hline & $\begin{array}{l}\sqrt{ } \text { The province commissions the Dutch } \\
\text { paying agency to only approve group } \\
\text { applications of group that are in } \\
\text { accordance with the regional plan }\end{array}$ & $\begin{array}{l}\sqrt{ } \text { WLD pays individual farmers and can } \\
\text { decide herself on payment framework }\end{array}$ & - \\
\hline \multirow[t]{2}{*}{ Evaluation } & $\sqrt{ }$ Province and national government & $\begin{array}{l}\text { - No formal role, but WLD influenced } \\
\text { the change of the system }\end{array}$ & $\begin{array}{c}\sqrt{ } \text { Research institutes commissioned } \\
\text { by government }\end{array}$ \\
\hline & $\sqrt{\text { Province }}$ & - WLD evaluates at management level & $\sqrt{ }$ Unchanged \\
\hline
\end{tabular}

*** Source: OECD 2013 (Table 13.1) 